\title{
A TEMPORALIDADE COMO CONDICCÃO DE POSSIBILIDADE DA COMPREENSÃO DO SER DO ENTE SIMPLESMENTE PRESENTE À VISTA (VORHANDEN)
}

\author{
Estevão Lemos CRUZ* \\ doi: 10.11144/Javeriana.uph36-73.tspv
}

\section{RESUMO}

O presente estudo pretende compreender como a temporalidade é a condição de possibilidade da compreensão do ser do ente enquanto simplesmente presente à vista (Vorhanden). Para tanto, buscaremos expor um esboço da estrutura da temporalidade desenvolvida por Heidegger em Ser e tempo e em Os problemas fundamentais da fenomenologia. A exposição de tal estrutura permitirá, então, mostrar como a presentidade - e, portanto, o ente que carrega tal modo de ser - somente pode manifestar-se em um presente (Gegenwart).

Palavras-chave: Heidegger; temporalidade; Vorhanden; presente (Gegenwart)

Universidade Estadual do Paraná, União da Vitória, Brasil.

Correo electrónico: estevaolemoscruz@yahoo.com.br

Para citar este artículo: Cruz, E. L. (2019). A temporalidade como condição de possibilidade da compreensão do ser do ente simplesmente presente à vista (Vorhanden). Universitas Philosophica, 36(73), 147-186. ISSN 0120-5323, ISSN en línea 2346-2426. doi: 10.11144/Javeriana.uph36-73. tspv 


\title{
TEMPORALITY AS A CONDITION OF POSSIBILITY OF THE UNDERSTANDING OF BEING OF THE BEING PRESENT-AT-HAND (VORHANDEN)
}

\begin{abstract}
The present study aims to understand how temporality is the condition of possibility of that understanding-of-being which understands beings as present-at-hand (Vorhanden). To do so, we will try to present an outline of the structure of temporality developed by Heidegger in Being and Time and in The Basic Problems of Phenomenology. The exposition of such a structure will then allow us to show how presentness-and therefore the entity that has this mode of being — can only come to the fore in a present (Gegenwart).

Keywords: Heidegger; temporality; Vorhanden; present (Gegenwart)
\end{abstract}


Certamente a tese mais marcante do pensamento heideggeriano sintetiza-se na afirmação de que a interpretação do tempo é "o horizonte possível de toda e qualquer compreensão do ser em geral" (Heidegger, 2008, p. 34). A investigação que sustenta essa conhecida afirmação corresponde não só à meta provisória desenvolvida em Ser e tempo, mas ao esforço cabal da obra nos limites em que nos foi entregue. A mesma tese é retomada em Os problemas fundamentais da fenomenologia, mas agora a partir de outra perspectiva que toma como fio condutor "algumas teses tradicionais sobre o ser" (2012a, p. 43). Heidegger consegue, assim, demonstrar o modo como a questão do ser é elaborada na tradição filosófica em consonância com o problema do tempo sem limitar-se à circunscrição de uma filosofia existencial ${ }^{1}$.

Pois bem, se a afirmação de Heidegger é correta e toda compreensão de ser se diz a partir do tempo, então o tempo, ou melhor, a temporalidade (Zeitlichkeit) é o sentido de ser do ente que é ele mesmo compreensão de ser, o Dasein ${ }^{2}$. Ademais, a compreensão de tudo o que há, de cada um dos entes, necessariamente deverá se deixar perceber desde algum aspecto do tempo, pois na medida em que o tempo é o horizonte da compreensão de ser, ele é o que permite que algo seja compreendido como sendo algo. Dadas tais conclusões próprias do pensamento heideggeriano, o objetivo de nosso estudo será investigar como o ente que tem o modo de ser daquilo que se encontra presente à vista (Vorhandenheit) se deixa compreender a partir do tempo. Para tanto, caberá esclarecer quais são os aspectos do tempo que estão em jogo na compreensão de tal ente e como esta mesma compreensão e seus aspectos temporais correspondentes fundam-se na trama da

1 Para uma visão geral de como o problema do tempo surge nas investigações do jovem Heidegger alinhado ao pensamento de Husserl é útil o artigo de Dostal (1993), Time and Phenomenology in Husserl and Heidegger.

2 Sobre o tema da temporalidade como sentido de ser do Dasein vale citar as conhecidas obras de Másmela (2002), Martin Heidegger: el tiempo del ser, que traz em seu primeiro capítulo, "La temporalidad como el sentido del Ser en Ser y Tiempo", os argumentos de Heidegger de modo bastante esquemático e sucinto; Dastur (1999), Heidegger and The Question of Time, que, depois de expor no primeiro capítulo a conexão entre a questão do ser e a questão do tempo, explicita clara e sinteticamente a temporalidade do Dasein; e von Herrmann (2004, pp. 76-91), Subjekt und Dasein. Sobre tal tema são úteis também os estudos de Käufer (2013), Temporality as the Ontological Sense of Care e White (2005, p. 93), Time and Death. Heidegger's Analysis of Finitude. 
temporalidade que constitui o sentido de ser do Dasein. Convém, no entanto, esclarecer antecipadamente a interpretação que o jovem Heidegger desenvolve acerca do tempo ${ }^{3}$.

\section{Compreensão vulgar do tempo e temporalidade}

O QUE ENTENDEMOS COTIDIANAMENTE POR TEMPO não é algo difícil de ser apreendido. Ele se caracteriza por ser uma duração contínua e indefinida formada pela ininterrupta sucessão de "agoras". Essa compreensão do tempo é o que Heidegger (2012a) chamou de "conceito vulgar de tempo" ou "tempo do relógio", "tempo do agora” (pp. 372 e ss). Tal denominação se deve ao fato de que o "agora" é o elemento fundamental de tal compreensão e pelo qual todos os outros aspectos do tempo se determinam. O passado é o agora que já aconteceu e que já não é mais, é o agora não mais presente. $\mathrm{O}$ futuro, por sua vez, é o agora que ainda não é chegado, que ainda não se fez presente. Todos os aspectos do tempo se relacionam, portanto, a esse agora/presente. Entretanto, é sempre necessário ressaltar - haja vista que tal caracterização do tempo como uma compreensão "vulgar" poder denotar um tom pejorativo - o fato de que tal compreensão não é algo essencialmente ruim, mas, ao contrário, indispensável à manutenção da vida comum. É com base nela que planejamos nosso dia e orientamos nossos compromissos $^{4}$. No entanto ela realmente pode ser perigosa quando, não mais pensada,

3 Não serão objeto de nosso estudo as posturas interpretativas acerca do tempo que Heidegger desenvolveu tardiamente e que alcançaram sua maturidade em Beiträge zur Philosophie (1989). Sobre o tema do tempo em conexão com a virada do pensamento heideggeriano, vide Másmela (2000; 2016), Dastur (1999), von Hermman (1997) e von Falkenhayn (2003). Quanto aos estudos acerca da interpretação do tempo desenvolvida pelo jovem Heidegger vale citar Heinz (1986), The Concept of Time in Heidegger's Early Works (pp. 183-207); Massey (2015), The Origin of Time. Heidegger and Bergson (pp. 11-48); Nicholson (1986), Ekstatic Temporality in Sein und Zeit, e Sembera (2007), Rephrasing Heidegger.

4 Pode causar algum estranhamento quando nos referimos à compreensão vulgar ou imprópria do tempo de modo não exclusivamente negativo, mas como algo necessário. Tal estranhamento tem a ver com o fato de que muito do trabalho de Heidegger, em Ser e tempo, é abrir espaço para a compreensão da possibilidade mais própria do Dasein. Contudo, é na compreensão vulgar do tempo que o Dasein se move na impropriedade. Esta, por sua vez, é parte fundamental e integra o modo de ser desse Dasein. Perceba-se que a analítica existencial de Ser e tempo não é apenas uma análise do Dasein em sua possibilidade própria, mas igualmente uma análise de sua impropriedade. Os dois 
modos são igualmente constitutivos do Dasein e, portanto, jamais nos livramos permanentemente deste último. É fundamental não perdermos de vista tal possibilidade e a cotidianidade do Dasein. É na impropriedade que o homem se organiza, trabalha, escreve, relaciona-se com os outros, etc. Tais atividades do cotidiano, necessárias à manutenção da vida social, não se fazem possíveis no instante em que o Dasein é lançado à sua possibilidade mais própria. O Dasein em seu ser próprio - no instante em que rompe, pela angustia ou pelo tédio, com a dispersão da cotidianidade e, tomando consciência de sua finitude, assume sua possibilidade mais própria: ser-para-a-morte - não vai ao mercado e nem escreve livro de filosofia. É necessário o retorno à impropriedade para que se possa desenvolver as atividades cotidianas, isto é, é necessário deixar de compreender-se a partir de si mesmo e voltar a compreender-se a partir das relações de trabalho, das relações de consumo, etc. Ao Dasein, em seu modo próprio, só resta uma possibilidade: ser para a morte - a possibilidade da impossibilidade de todas as possibilidades. Contudo, isso jamais significa que o filósofo é aquele que não vai ao mercado ou trabalha. De modo algum. O que se está dizendo é que a propriedade não é uma possibilidade em que o Dasein se demora e pode passar a "viver" nela. Não é algo como um "estilo de vida". A ruptura que caracteriza a propriedade, como veremos adiante, dar-se em um "instante", em um "susto" que retira o Dasein de sua familiaridade em meio a ocupação. A propriedade, enquanto tal susto, não tem duração cronológica - quando nos apercebemos dela, ela já se foi. É a partir de tais prerrogativas que entendemos que a impropriedade e sua respectiva compreensão vulgar do tempo são indispensáveis à vida. Ademais, é necessário perceber o modo como já estamos sempre lidando com o "agora" em todas nossas atividades cotidianas. Sobre isso, diz Pearl (2013): “implicitamente, o Dasein já está sempre dizendo 'agora' quando se envolve, cuida e emprega algo presente em seu mundo. Ao colocar o livro sobre a mesa, ao olhar para um parágrafo bem escrito, ao andar pela rua, estou me referindo ao livro que li, ao conteúdo que me moveu e à Rua Sirkin como sendo (como existindo). Não é totalmente diferente para mim dizer, implicitamente, 'ainda não agora', ao afirmar que este parágrafo não está bem formulado ou, por exemplo, quando o pai de uma criança pequena diz 'você ainda não pode atravessar rua por si mesmo'. Quando nos expressamos dessa maneira, estamos na verdade nos direcionando para algo no futuro. Ao dizer implicitamente 'não mais agora', ao recusar educadamente a sobremesa depois de uma refeição saudável, estamos, de fato, nos direcionando para algo no passado" (p. 57; tradução nossa). ["Implicitly, Dasein is always already saying 'now' as it engages with, takes care of and employs something present in its world. In putting the book down on the table, in looking over a well-written paragraph, in walking down the street, I am relating to the book I've read, to the contents which moved me and to Sirkin street as being (as existing). It is not entirely different for me to say, implicitly, 'not-yet-now', in stating that this paragraph is not well-phrased or, for instance, when the father of a small child says 'you can't cross the street by yourself. When we express ourselves in this manner, we are actually directing ourselves to something in the future. In implicitly saying 'no-longernow', while politely refusing dessert after a bealthy meal, we are, in fact, directing ourselves toward something in the past"]. Pearl chama atenção aqui para o fato de que nossas atividades do cotidiano estão implicitamente orientadas desde o "agora". Por sua vez, a compreensão do tempo enquanto "agora" funda-se em autointerpretações de comportamento que revelam a modulação imprópria da temporalidade. Como consequência, temos que as ações do cotidiano já tomam como ponto de partida a compreensão vulgar do tempo. O "tempo do trabalho", o "tempo do mundo" é o tempo do "agora". Sembera (2007) também corrobora nossa posição: "É impossível acabar com o conceito vulgar de tempo porque este é o 
passa a encobrir o tempo em sua compreensão mais própria ou impor-se como o modo apropriado para a interpretação de estruturas ontológicas. Mas, de qual pressuposto nos valemos quando afirmamos que este sentido do tempo não é o mais próprio na investigação das estruturas ontológicas ${ }^{5}$ e qual seria, por conseguinte, o sentido mais próprio do tempo para tal tarefa?

Dois pressupostos principais nos impedem de tomarmos a compreensão vulgar do tempo como seu sentido mais próprio. O primeiro e mais evidente é que no "tempo dos agoras" - no qual o "agora" é o que há de vir no futuro e o que foi deixado para trás no passado - os "agoras" são tomados e compreendidos como sendo eles mesmos alguma coisa que está no tempo, a saber, o agora que está no futuro e o agora que ficou no passado. Por se mover ele mesmo como "algo no tempo", arrogando para si um caráter ôntico, o "agora" não pode, consequentemente, dar conta de explicar a temporalidade enquanto fundamento ontológico. O segundo pressuposto move-se também na mesma linha da diferença ontológica, mas toca diretamente os objetos de nossa investigação. Tal pressuposto reside no fato de que "o que se faz presente" no "agora" tem sempre o modo de ser do que "está aí" (Vorhandenheit). Por sua vez, quando falamos de comportamentos existenciais do Dasein, não podemos atribuir a eles o modo de ser daquilo que não é Dasein, isto é, dos entes que estão aí e que se fazem presentes neste contexto

tempo que caracteriza o Dasein em sua cotidianidade média. Sem essa concepção do tempo seria impossível administrar de alguma forma o nosso tempo - medir o tempo decorrido, aceitar nos encontrarmos ao mesmo tempo e organizar nosso tempo para tudo o que formos fazer. [...] A decadência e, portanto, a falta de autenticidade estão ambas ancoradas na própria estrutura do Dasein. A autenticidade, portanto, não pode consistir em extirpar a inautenticidade da esfera da experiência humana" (p. 221; tradução nossa). ["It is impossible to do away with the vulgar concept of time, because it is the time characterizing Dasein in its average everydayness. Without this conception of time it would be impossible to manage our time in any way-to measure elapsed time, to agree to meet at the same time, and to arrange our time so as to get everything done. As we have repeatedly seen in the course of our interpretation of Being and Time, falling and therefore inauthenticity are both anchored in the very structure of Dasein itself. Authenticity, therefore, cannot consist in excising inauthenticity from the sphere of human experience"]. Acerca dos estudos desenvolvidos sobre a impropriedade em Heidegger é útil a obra de Rozo (2005), Fuera de casa o de la existencia impropia. Hacia otra lectura de Ser y Tiempo de Heidegger. Quanto ao conceito "vulgar/cotidiano" de tempo vale conferir os estudos de Peñalver (1989), Del espiritu al tiempo (pp. 204-232) e von Falkenhayn (2003), Augenblick und Kairos - Zeitlichkeit im Frubüwerk Martin Heideggers (p. 126).

5 Estruturas ontológicas refere-se aqui aos existenciais que constituem o ser do Dasein. 
de passado, presente e futuro do "tempo do agora". Esse modo de ser de fazer-se presente aí é típico e exclusivo dos entes ${ }^{6}$ e não das estruturas ontológicas. Tais estruturas, portanto, não podem deixar-se entender desde tal compreensão do tempo sob pena de invocarem para si um caráter do ente ${ }^{7}$. Mas, se elas não podem se orientar pelo "tempo do agora", como podem se deixar traduzir em termos "temporais"? Que compreensão de tempo deve se impor a tais estruturas?

Se por um lado a compreensão comum de tempo não é apta para expor o caráter temporal das estruturas ontológicas, por outro, pode nos fornecer o ponto de partida para uma reflexão acerca do sentido mais originário do tempo. Ao pôr em análise o problema da compreensão vulgar de tempo, o "tempo do relógio", Heidegger (2012a) propõe a pergunta pelo quê significa olhar para o relógio. Em suma, ele responde que o que é buscado quando se olha o relógio nunca é o tempo enquanto tal, o tempo ele mesmo, mas uma determinação quantitativa que me orienta justamente nesse quanto falta para que eu possa fazer isto ou aquilo, quanto tempo eu ainda tenho para tal ou qual atividade (pp. 374-375). O "olhar o relógio" é sempre visar um "agora" a fim de "tomar tempo para...". Entretanto, diz Heidegger, para que eu possa "tomar tempo para...", é necessário que esse tempo já me tenha sido dado, ou seja, é necessário que já contemos previamente com ele para que, inclusive, possamos medi-lo? Sua mensuração quantitativa

6 "Apenas tal ente, que tem o caráter do estar aí presente, tem em si mesmo o seu sentido de ser para a possibilidade da sucessão (da sequência) e do atravessamento por um agora. Dizemos também que o ente cai no tempo ou, mais exatamente, que cai a cada vez em um agora. Assim, dito de modo inverso, se algo está determinado temporalmente neste sentido, então significa que este algo tem o modo de ser do que está aí presente” (Heidegger, 1976, p. 244, tradução nossa).[„,Nur solches Seiendes, das den Charakter des Vorhandenseins hat, hat in sich selbst seinem Seinssinne nach die Möglichkeit der Abfolge und des Durchgangs durch ein Jetzt. Wir sagen auch, das Seiende fällt in die Zeit, genauer gesprochen, es fällt jeweils in ein Jetzt. Wenn also umgekehrt etwas in diesem Sinne zeitbestimmt ist, dann besagt das, daß dieses Etwas die Seinsart des Vorhandenen hat."]

7 Sobre os motivos pelos quais a concepção vulgar de tempo é insuficiente para a analítica do Dasein, cf. Agustín Corti (2006, p. 119-121).

8 Dito de modo rigoroso, este "visar o agora" no relógio nunca intenciona o agora ele mesmo, mas aquilo de que me ocupo, aquilo que demanda meu tempo e com que me preocupo. Quando olhamos para o relógio intencionamos a "aula que vai começar", "o término de um jogo", etc.

9 "Quando atentamos para o fato de que, no uso do relógio, com vistas ao relógio, já sempre reside a cada vez um contar com o tempo, então isso significa que o tempo já nos é dado antes do uso do 
seria, portanto, uma modificação do modo como me relaciono com este tempo no qual eu sempre me movo, o que é o mesmo que dizer que esse "tomar tempo para..." do relógio, o tempo vulgar, funda-se em uma temporalidade prévia. Mas que base temporal é essa na qual se orienta a compreensão mediana de tempo?

\subsection{CompreENSÃo VULGAR E "AUTOINTERPRETAÇÕES DE COMPORTAMENTOS"}

É CERTO QUE O TEMPO, ele mesmo, não é algo que pertence ao relógio, mas algo que lhe "emprestamos", que lhe entregamos de antemão para que ele possa dizer quanto tempo ainda temos. Por não pertencer ao relógio, o tempo confiado a ele necessariamente precisa remeter a uma origem desde a cual a compreensão vulgar se interpreta. Tal interpretação, diz Heidegger (2012a), baseia-se em "autointerpretações de comportamentos" (Selbstauslegung von Verhaltungen) (p. 377). O que isso quer dizer? Heidegger, em Os problemas fundamentais da fenomenologia, nos diz que o tempo da compreensão comum, como já adiantado, é uma sequência de agoras que se orienta a partir do agora-ainda-não em direção ao agora-não-mais. Ou seja, tal compreensão se move nas determinações temporais do "agora", "em seguida" e "outrora" (Jetzt - Dann - Damals). Tais determinaçôes, por sua vez, encontram suas possibilidades enquanto autointerpretaçôes de comportamento. Por exemplo, o "em seguida", afirma Heidegger, só pode ser dito quando se está na expectativa, na "expectação" (Gewärtigen) de algo. Somente na medida em que nos nutrimos de expectativas podemos dizer "em seguida". O "em seguida” é, assim, uma autointerpretação de um determinado modo de comportamento que é a "expectação". Do mesmo modo, o "outrora" também só encontra seu sentido enquanto autointerpretação de um comportamento. $\mathrm{O}$ comportamento que funda a possibilidade do "outrora" é a "retenção" (Behalten) enquanto a manutenção de algo que já aconteceu. Por sua vez, o "agora” só é possível a partir de um dispor-se frente a algo que se apresenta e que se faz manifesto à vista. Tal comportamento é o que Heidegger (2012a) chama de "presentificar", "presentificação" (Gegenwärtigen) de algo (p. 377). Expectação,

relógio, que ele de algum modo é desvelado de antemão para nós e que somente por isso podemos retomar expressamente a ele com o relógio" (Heidegger, 2012a, p. 375). 
retenção e presentificação são os nomes que Heidegger dá a esses comportamentos prévios que permitem que o "em seguida", o "outrora" e o "agora" encontrem suas respectivas interpretações. Porém, assim como o "agora" se manifesta em cada determinação temporal, a "presentificação" (Gegenwärtigen) também configura uma unidade entre esses comportamentos. A “expectação”, por exemplo, é a expectativa da realização ou não de algo no presente, é o expectar da presentificação (Gegenwärtigen), é o ainda-não em uma presentificação. A "retenção", por outro lado, é sempre um manter de volta no presente, é um reter na presentificação (Gegenwärtigen). O que se exprime na origem do "agora" visado no relógio não é, portanto, qualquer objeto ou algo que se faça presente - o que se exprime enquanto possibilidade desse olhar é justamente a "presentificação" (2012a, p. 379).

Quanto a esta organização das autointerpretações de comportamentos proposta por Heidegger, concordamos com Martin Thomé (1998):

O ponto de honra desse discurso é que o Dasein expecta um determinado ponto do tempo ou é retido como estando em determinado ponto do tempo. O "em seguida", o "outrora" e o "agora" enquanto três modos fundamentais de expressar o tempo referem-se primariamente a algo presente [Anwesendes], que em sua presentidade [Anwesenheit] é expectado, retido e presentificado (p. 162; tradução nossa). ${ }^{10}$

É interessante perceber que toda essa análise de Heidegger acerca do tempo parte da percepção de que "experimentamos o tempo no comportamento prático" (Corti, 2006, p. 114). São esses comportamentos que orientam o modo como interpretamos o tempo e, inclusive, possibilitam inventar algo como o

10 „Bezugspunkt in dieser Rede ist das, was das Dasein an einem bestimmten Jetztpunkt gewärtigt bzw. was als an einem bestimmten Jetztpunkt Gelegenes behalten wird. Das Dann, Damals und Jetzt als die drei grundsätzlichen Weisen des Aussagens von Zeit beziehen sich primär aufje Anwesendes, das in seiner Anwesenheit gewärtigt, behalten und gegewärtigt wird." É ponto pacífico na literatura crítica o modo como a compreensão vulgar do tempo se estrutura nas "autointerpretações de comportamento" [Jetzt/Gegenwärtigen - Dann/Gewärtigen - Damals/Behalten]. Além da obra de Martin Thomé - que traz um interessante trabalho sobre o tema da precariedade (Prekarietät) na temporariedade do Dasein -, ocupam-se explicitamente da questão da "autointerpretação de comportamentos” os trabalhos de Agustín Corti (2006) e Helmuth Vetter (2016). Este último vale-se das análises heideggerianas sobre a compreensão vulgar de tempo, que se origina a partir das considerações aristotélicas (Física IV, 10-14), para comentar algumas passagens do poema de Parmênides. 
relógio, que é aferido de antemão por esta mesma interpretação em que já nos movemos. Diz Corti (2006):

Nós geralmente precisamos de um relógio para averiguar a determinação do tempo. Mas essa determinação não é essencial em um relógio, ele apenas nos orienta em certo comportamento. $\mathrm{O}$ argumento de Heidegger é que, se olharmos para o relógio, não queremos ver o relógio ou ler a hora. O relógio não direciona alguém para o tempo enquanto tal, mas no uso do relógio a pessoa tem de alguma forma o tempo; o tempo deve ser anterior a qualquer uso para ser possível ver sua determinação no relógio. Mas isso significa que essa determinação do tempo, lida a partir do relógio, não é o tempo em si, mas uma interpretação dele (p. 114; tradução nossa $)^{11}$.

Contudo, pode o próprio tempo ser compreendido em seu sentido mais originário a partir de tais autointerpretações de comportamentos e da unidade entre eles no Gegenwärtigen? Não. Tais comportamentos representam a modulação imprópria da temporalidade. Mas como podemos pensar, então, o sentido originário do tempo?

\subsection{A MODULAÇÃO AUTÊNTICA E INAUTÊNTICA DA TEMPORALIDADE. O SENTIDO ORIGINÁRIO DO TEMPO}

É CERTO QUE O TEMPO, ele mesmo, não pode ser originariamente pensado a partir da sucessão ininterrupta de vários "agoras" enfileirados. O "agora”, o "em seguida" e o "outrora", pensados desde uma sucessão linear, são manifestações, isto é, expressões pertencentes à compreensão vulgar do tempo e, como tais, não podem elas mesmas aclarar o sentido originário do tempo que as possibilita. Que tais determinações correspondam à compreensão vulgar do tempo significa que elas derivam de estruturas mais originárias que, por sua vez, correspondem

11 „Wir brauchen gewöhnlich eine Uhr, um die Bestimmung der Zeit auf ihr festzustellen. Aber diese Bestimmung liegt gerade nicht wesentlich in einer Uhr, sondern sie leitet uns nur in einem gewissen Verhalten. Heideggers Argument lautet: wenn wir auf die Uhr sehen, wollen wir weder die Uhr sehen noch die Zeit ablesen. Die Uhr richtet jemanden nicht auf die Zeit als solche, sondern im Gebrauch der Uhr hat man schon irgendwie die Zeit; die Zeit soll früher als jeder Gebrauch gehabt werden, um deren Bestimmung auf der Uhr sehen zu können. Das heißt aber, dass diese von der Uhr abgelesene Bestimmung der Zeit nicht die Zeit selbst ist, sondern bereits eine Auslegung dieser." 
à compreensão originária de tempo. Dito de outro modo, uma compreensão só pode ser "vulgar" porque ela em sua di-vulgação retira algo de seu caráter singular, irrevelado, não expresso. A pergunta, então, que devemos fazer quando almejamos o sentido originário do tempo é: qual é o caráter não expresso do tempo? Heidegger (2012a) responde: A temporalidade (Zeitlichkeit) é o fenômeno originário do tempo e corresponde à unidade originária das ekstases do futuro (Zukunft), do sido (Gewesenheit) e do presente (Gegenwart) (p. 387). Mas, o que quer dizer uma resposta como essa? Para entendê-la, é fundamental que fique previamente esclarecido que a temporalidade não pode ser pensada meramente como:

uma composição do futuro [Zukunft], vigor de ter sido [Gewesenheit] e presente [Gegenwart]. Essas dimensões são modalidades temporais cooriginárias da totalidade e devem ser compreendidas, como tais, dentro da montagem articulada do todo em sua íntima implicação recíproca. A temporalidade é a unidade articulada do futuro, vigor de ter sido e presente, o que significa que essa triplicidade deve ser estabelecida com base em sua integridade estrutural como unidade (Másmela, 2000, p. 81; tradução nossa) $)^{12}$.

É fundamental ter em mente a diferença entre o que é mera "composição" e o que diz respeito a "unidade" de uma integridade estrutural. Enquanto a mera composição traduz-se como uma justaposição de elementos distintos e separados, a unidade em jogo na temporalidade reflete a indissociabilidade dos momentos que a constituem. Não é possível, por exemplo, compreender a ekstase do "vigor de ter sido" sem levar em conta que ela perfaz um acontecimento de arroubo único com as ekstases do futuro e do presente, articulando-se simultaneamente como totalidade (Másmela, 2000, p. 85). Dito isto, cabe voltarmos a perguntar: o que Heidegger está chamando de ekstases? E como a unidade delas possibilita a compreensão mais originária do tempo?

12 "una composición de advenir [Zukunft], sido [Gewesenheit] y presente [Gegenwart]. Estas dimensiones son modalidades temporales cooriginarias de la totalidad y tienen que comprenderse, como tales, dentro del ensamblamiento articulado del todo en su intima implicación reciproca. La temporalidad es la unidad articulada de futuro, sido y presente, lo cual significa que esta triplicidad tiene que establecerse con base en su integridad estructural como unidad". 


\subsubsection{A temporalidade como unidades das ekstases: a ekstase do "futuro" (Zukunft)}

HeIDEgGer nOS FALA QUE NA EXPECTAÇÃo, isto é, quando nos nutrimos de expectativas, compreendemos a nós mesmos a partir das coisas com as quais nos encontramos ocupados. Na medida em que nos compreendemos de tal modo, nós voltamos a nós mesmos como aquilo que nós mesmos não somos. Por exemplo, ao olhar para o relógio expectando o começo da aula, compreendo a mim mesmo a partir da aula e, consequentemente, já tomo a mim mesmo como "aluno" ou "professor". O Dasein, segundo Heidegger (2012a), chega a si mesmo, portanto, pela expectação a partir das coisas (p. 420). Contudo, só podemos expectar a nós mesmos a partir dos entes que nos circundam porque carregamos em nosso modo de ser a possibilidade desse "voltar-se para", de um "ir em direção a". Este "vir em direção a si mesmo" é o que de fato Heidegger quer enfatizar na palavra Zu-kunft (futuro). Lembremos que a preposição $z u$, que co-forma Zukunft, significa, sobretudo, 'para'e que o substantivo Kunft provém do verbo kommen, que significa 'vir', 'chegar'. Zukunft carrega em sua etimologia, portanto, o sentido de 'vir para'. Heidegger (2012a) se apropria dessa etimologia e caracteriza o sentido primário de futuro como o "vir para si mesmo" do Dasein (p. 385). O futuro (Zukunft) diz respeito, então, a um "chegar a si mesmo" que o próprio Dasein é enquanto projetar de possibilidades. "O Dasein advém para si mesmo no futuro" (Másmela, 2000, p. 73). Agora, deve-se levar em consideração também o seguinte: o Dasein, ele mesmo, só pode se mover na expectativa de algo se já é dado a ele de antemão a possibilidade projetar sentido, se ele, enquanto tal, for um poderser. Dito de outra forma, se ao Dasein fosse negado seu caráter de ser-possível, então ele não poderia ter expectativa alguma, ou seja, pensar-se na expectativa de alguma possibilidade e decidir por ela ${ }^{13}$. A expectação e, consequentemente,

13 "Meu ser não é transportado no futuro porque eu tenho uma visão do futuro, mas eu apenas posso visualizar o futuro porque meu ser, enquanto ex-istente, essencializa no modo básico de deixar o que está vindo vir em sua direção, no ser transportado para o vir” (Heidegger, 2006a, p. 50; tradução nossa). ["Mein Sein ist nicht in die Zukunft entrückt, weil ich eine Vorstellung von der Zukunft habe, sondern ich kann Zukünftiges nur vorstellen, weil mein Sein als Da-sein in der Grundart west, Kommendes auf sich zukommen zu lassen, in das Kommen entrückt zu sein."] A palavra alemã Entrückung tem um apelo semelhante ao da palavra grega ह̌̋ $\sigma \tau \alpha \sigma \iota \zeta$ Cabe lembrar que esta provém

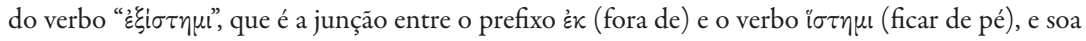


o "em seguida" que se funda nela, só são possiveis, portanto, sob a base do futuro (Zukunft) entendido em seu sentido originário enquanto voltar em direção a si mesmo, lançar-se continuamente em suas possibilidades.

Por ser tal lançar, a ekstase do futuro entrega ao Dasein o seu caráter de projeto, de "lançado ao mundo". Isso, por sua vez, significa várias coisas, mas devemos atentar, sobretudo, a três consequências. A primeira é que, se o futuro é o que entrega ao Dasein o seu caráter de projeto e o Dasein é ele mesmo projeção, significa que não há Dasein sem temporalidade, que a temporalidade é essencialmente constitutiva de tal ente ou, dito melhor, que o Dasein mesmo é a temporalidade. A segunda consequência é que temos que lembrar que este "lançar-se" que está em jogo no futuro também entrega ao Dasein seu "para fora". Na medida em que o futuro lança o Dasein em suas possibilidades, ele o abre a si mesmo neste "para fora de si" ${ }^{14}$, isto é, ele entrega o Dasein ao seu caráter de aberto (Erschlossenheit),

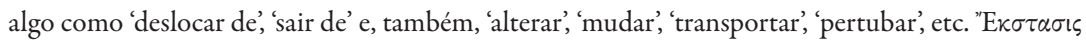
indica, assim, um 'deslocamento', um 'sair de si' e, por derivação, um 'êxtase. Entrückung, por sua vez, deixa soar algo semelhante tal como um 'arrebatamento', um 'ser transportado', uma 'perturbação' Por carregarem tal semelhança, estas palavras são muitas vezes usadas como sinônimo por Heidegger.

14 O Dasein na terminologia de Ser e tempo é essencialmente "para fora de si", isto é, ek-stático. O "Da-" em jogo no Da-sein aponta justamente para um essencial "estado de aberto" pelo qual o Dasein exsiste para si mesmo. Mas dizer que é pelo seu "estado de aberto" que o Dasein ex-siste para si mesmo implica dizer também que este "Da-" é a própria "essência" do Dasein. Mas, no que consiste a "essência” deste ente? A "essência” deste ente consiste no fato de que ele é de tal maneira que, sendo, compreende algo assim como o ser. É só porque o Da-sein é essencialmente "para fora de si” - não fechado, encerrado em si mesmo - que ele pode projetar sentido, compreender ser e, em especial, compreender a si mesmo como sendo. Sua "essência", portanto, reside na relação na qual o Dasein já sempre se comporta, desta ou daquela maneira, com o seu ser. O ser com o qual o Dasein se comporta é o que Heidegger chamou de existência (Existenz). Tal existência diz o essencial modo de ser do Dasein pelo qual ele está lançado em uma facticidade (projetado para fora de si), isto é, está entregue à sua própria ex-istência. Vale sempre a pena lembrar que a palavra existência remete-se em sua significação originária à palavra latina ex(s)istentia, que vem do verbo exsisto e que, por sua vez, diz um 'elevar-se para fora de,' 'elevar-se acima de,' 'aparecer', 'deixar-se ver,' 'mostrar-se'; 'sair de', 'provir de,' 'nascer de'; 'apresentar-se', 'manifestar-se'; 'existir,' 'ser'; 'consistir,' 'resultar'. Deste modo, ao carregar estes significados, a palavra ex-sistência denuncia o essencial modo de ser do Dasein, a saber, que, ex-sistindo, o Dasein é elevado para fora de si mesmo e é lançado, entregue numa compreensão de ser. Portanto é ex-sistindo que o Dasein compreende ser. Esta "saída de si mesmo" que possibilita compreender ser é o que irá marcar o caráter de aberto do Dasein. Em outras palavras, a ex-sistência do Dasein aponta para uma saída de si mesmo que proporciona a este ente uma abertura 
à sua transcendência. $\mathrm{O}$ Dasein é transcendente na medida em que se move enquanto projeção de sentido. Isso quer dizer que a temporalidade éo "para fora" que possibilita a transcendência do Dasein, sua ex-istência ${ }^{15}$. Por isso, Heidegger (2008) diz que a temporalidade é essenciamente ekstática ${ }^{16}$. Sobre isso, diz ele: a

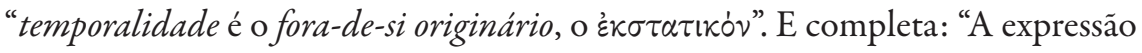

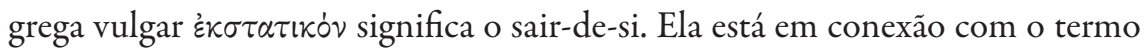
'existência”" (2012a, p. 388). Assim, o "zu-" em jogo em Zu-kunft, bem como o "ek-" que dão a tônica nas palavras "ek-stases" e "ek-sistência", apontam para o mesmo fenômeno: a abertura ao ser, o caráter transcendental do Dasein. Tal afirmativa, além de corroborar a primeira consequência anunciada, demonstra, de uma vez por todas, que Heidegger pensa o modo originário do tempo em consonância com o modo de ser que é próprio do Dasein ${ }^{17}$. A parte isso, a segunda consequência nos fornece também o gancho para pensar em uma terceira consequência da interpretação de Heidegger (2008) acerca da ekstase do futuro, a saber, que esta ekstase é o que temporaliza originariamente a temporalidade (p. 416) ${ }^{18}$. Ora, isso se evidencia pelo fato de o futuro, ao constituir o projetarse do Dasein em suas possibilidades, dar o tom geral do movimento ekstático, do "para fora", da temporalidade e, consequentemente, da existencialidade do

que lhe possibilita uma relação com seu ser, consigo mesmo e com os demais entes (Heidegger, $2008, \$ 4 / 9)$.

15 Sobre a relação entre transcendência e temporalidade vide a preleção de Heidegger (1978): Metaphysische Anfangsgründe der Logik im Ausgang von Leibniz, $\$ 11$, 12 e 13 (pp. 203-289).

16 A consequência apresentada aqui corresponde à segunda tese de Heidegger acerca da temporalidade. Heidegger (2008) nos fala em Ser e tempo que a análise da temporalidade poderia ser resumida em quatro teses: "originalmente, tempo é temporalização da temporalidade que, como tal, possibilita a constituição da estrutura da cura. A temporalidade é, essencialmente, ekstática. Temporalidade temporaliza-se, originariamente, a partir do porvir [Zukunft]. O tempo originário é finito" (pp. 415-416).

17 Em Ser e Tempo, Heidegger (2008) não deixa dúvida alguma quanto a essa consonância quando procura analisar as ekstases da temporalidade em sua relação com as estruturas fundamentais que compõem a cura (Sorge).

18 Tal consequência corresponde à terceira tese de Heidegger acerca da temporalidade anunciada em Ser e tempo. 
Dasein ${ }^{19}$. O projetar do futuro é o movimento prévio que abre o Dasein no seu "para fora", sem o qual as outras ekstases não podem se orientar. Agora, que o futuro seja o "movimento prévio" ou, nas palavras de Heidegger, o "sentido primário" não significa que ele esteja dado antes como o primeiro elemento de uma série de sucessões, como se primeiramente viesse o futuro para que, então, só depois pudesse vir na sequência o passado e o presente. De modo algum. É sempre fundamental ter em mente que as ekstases formam uma unidade indissociável. O que Heidegger quer apontar é apenas uma primazia do futuro frente às outras ekstases. Apontar tal primazia não é senão dizer que só porque o Dasein projeta a si mesmo ele pode já encontrar-se desde sempre, ou melhor, ser jogado em um horizonte articulado de sentido no qual ele tem em vista a si mesmo e aos entes de uma forma ou outra. "Ter em vista" não é senão "projetar", "tencionar". Isso nos diz, de uma vez por todas, que o Dasein só pode "ter em vista" a si mesmo e os entes desta ou daquela forma ${ }^{20}$, isto é, articulados em um horizonte de sentido, por conta do projetar ou, o que é o mesmo, por conta de seu caráter "porvindouro"21 (zu-künftig) que o lança em suas possibilidades. Por isso, o futuro

19 'O projetar-se 'em virtude de si-mesmo', fundado no porvir, é um caráter essencial da existencialidade. O seu sentido primário é o porvir [Zukunft]" (Heidegger, 2008, p. 412). Sobre o primado da ekstase do futuro, vide Käufer (2013, pp. 356-357) e von Falkenhayn (2003, p. 112).

20 É importante fazer um adendo aqui sobre o fato de que, no projetar-se, o Dasein já sempre se tem em vista de uma forma ou de outra. Deve ficar claro que, embora o "vir para si" lance o Dasein no seu poder-ser, o Dasein não vem para si deliberadamente em seu poder-ser mais próprio. Ao contrário, ele vem para si na expectativa, na preocupação para com algo e, portanto, vem para si mesmo a partir do que o preocupa e, consequentemente, de modo inautêntico. Em outras palavras, ele há de se mover sempre na tendência de saber quem ele é a partir do mundo e dos entes com o qual ele se preocupa e não a partir de si mesmo. Quando o Dasein volta a si mesmo com vista àquilo de que ele se ocupa, isto é, com vista ao que está à sua volta, Heidegger nos diz que a ekstase do futuro caracterizar-se-á como um aguardar, expectar (Gewärtigen). No aguardar, o Dasein desvia-se de seu poder ser mais próprio para ter-se em vista a partir de seus afazeres e preocupações cotidianas.

21 É sempre uma tarefa bastante penosa e, por vezes, irrealizável encontrar soluções que traduzam a sensibilidade linguística que Heidegger apresenta em suas obras. Um exemplo dessa sensibilidade é o sentido de a "vinda para" que Heidegger escuta em Zukunft. A tradução brasileira de Ser e tempo opta por traduzir essa ekstase por "por-vir" - o que, sem dúvida, não é uma tradução ruim e ainda permite que sejam trabalhadas expressões como zu-künftig (por-vindouro). Entretanto, essa tradução pode nos ser traiçoeira se não atentarmos para o fato de que o futuro não é algo "por vir", isto é, não é algo que está por vir em direção ao Dasein, mas sim que diz respeito ao movimento do 
abre ao Dasein o seu poder ser e diz respeito originariamente, não a um "aindanão", mas a um comportamento fundamental do Dasein.

As considerações levantadas por Heidegger permitem concluir como a ekstase do futuro, enquanto um lançar-se em possibilidade, permite a expectação do Dasein que antecipa a si mesmo (Sich-vorweg) a partir dos entes dos quais ele se ocupa, em tal ou qual possibilidade determinada. Por sua vez, é essa expectação que permite ao Dasein interpretar o futuro como um ainda-não-agora.

Agora, o fato da expectação dizer respeito ao modo como o Dasein se antecipa $^{22}$ a partir daquilo que ele mesmo não é faz com que ela se configure como a modulação imprópria do futuro. No entanto, pode ocorrer da ekstase do futuro fazer com que o Dasein "chegue a si mesmo" não a partir dos entes que o circundam, isto é, não a partir daquilo que ele mesmo não é, mas a partir daquilo que ele mesmo é. Pode ocorrer que o lançar do futuro projete o Dasein em sua possibilidade mais própria. Quando isso ocorre, diz Heidegger (2006b), o Dasein adianta (vorlaufen) a si mesmo enquanto poder-ser. Adiantar-se quer dizer que ele é precursor frente à possibilidade de seu próprio poder-ser na medida em que se compreende a partir dele ${ }^{23}$. Dar-se aí o "antecipar [Vorlaufen] o poder ser de um

Dasein vindo para si mesmo. Compreender a ekstase do futuro como algo "por vir" é já pensá-la a partir da expectação, isto é, da Gewärtigen que caracteriza o futuro expresso e inautêntico.

22 Optamos por traduzir por "antecipar-se" o termo sich-vorweg, que diz respeito ao modo "formal e indiferente" como Heidegger designa o futuro. Para designar a modulação própria do futuro, a qual Heidegger chama Vorlaufen, utilizamos o verbo "adiantar".

23 O "adiantar-se" diz respeito a uma tomada de consciência do Dasein acerca de sua finitude. Essa possibilidade, que é uma possibilidade própria da transcendência e que retira o Dasein da dispersão da cotidianidade, está dada pelo que Heidegger chama de ser-para-a-morte. Não entraremos aqui em detalhes sobre o que constitui essa possibilidade derradeira do Dasein e nem como ela mesma chega a se formar como uma possibilidade, o que representaria um desvio considerável de nossa linha argumentativa. Contudo, cabe dizer algumas palavras sobre esse assunto - a partir de uma breve retomada do $\$ 53$ de Ser e tempo - para que melhor se compreenda o que se quer dizer com o "poder-ser mais próprio" do Dasein. Heidegger nos diz que "a morte é a possibilidade mais própria da presença [Dasein]. O ser para essa possibilidade abre à presença [Dasein] o seu poder-ser mais próprio [eigenstes Seinkönnen], em que sempre está em jogo o próprio ser da presença [Dasein]. [...] A possibilidade mais própria é irremissivel [unüberholbar]” (2008, p. 340). Sobre isso poderíamos começar dizendo que o ser-para-a-morte é ser para uma possibilidade, neste caso, uma possibilidade iminente do ser do Dasein. O ser-para-a-morte enquanto ser-possível aponta para o fim de toda possibilidade possível. Por isso ela é a possibilidade derradeira. Com a morte física, essa possibilidade 
ente cujo modo de ser é, em si mesmo, o antecipar [Vorlaufen]” (2008, p. 339). O "adiantar-se" (Vorlaufen) é a modulação própria da ekstase do futuro - que junto com as modulações próprias das ekstases do "presente" e do "vigor de ter sido" são "a mais originária no âmbito de um manancial de profusas articulações" (von Herrmann, 1997, p. 53)

iminente se esvai. Isso significa que o ser-para-a-morte enquanto possibilidade do Dasein é uma possibilidade do Dasein que vive e que, enquanto tal, pode estar na iminente possibilidade do fim de toda possibilidade. É enquanto possibilidade que o ser-para-a-morte deve ser compreendido e interpretado, o que, evidentemente, não se confunde com um "ficar pensando sobre a morte em seu quando ou como" ou um "ficar à espera da morte". Neste primeiro caso, há um enfraquecimento da possibilidade da morte por uma disposição que tende a calculá-la e, consequentemente, considerála dependente de nós. Já o "ficar à espera da morte" tende, como diz Heidegger, a tirar a morte do seu caráter de possibilidade ao arrastar essa possibilidade, pela espera, "para dentro do real". O ser-para-a-morte, ao contrário, é o maximamente distante do real. Ele não é a possibilidade para a realização de algo, mas o fim de toda a possibilidade de realização ou, dito com toda radicalidade, é "a possibilidade da impossibilidade de toda relação com..., de todo existir" (2008, p. 339), de toda a existência em geral. A morte, assim, não deve ser pensada como uma possibilidade que visa a sua efetivação, mas a partir da impossibilidade de toda existência. Ao deparar-se com essa possibilidade, continua Heidegger, o Dasein - que tem o modo de ser do "antecipar-se a si mesmo" adianta-se para a sua possibilidade mais derradeira e, portanto, para o seu poder-ser que lhe é mais próprio. Em tal poder-ser, o Dasein abre a si mesmo, isto é, há uma entrega de si à compreensão, um perceber-se de si em seu estado de lançado. Dito de modo direto, o ser-para-a-morte enquanto possibilidade de toda impossibilidade (a possibilidade mais extrema) abre ao Dasein o seu estado de aberto, de lançado e é justamente esse "abrir que adianta" o Dasein em seu estado de lançado que é o seu poder-ser próprio. Ser-para-a-morte é, portanto, um adiantar-se para o poder ser do ente cujo modo de ser é o próprio adiantar-se (2008, p. 339) e que, nesse adiantar-se, desvela ao Dasein esse poder ser como a sua possibilidade mais própria. Nisso consiste a modulação própria do futuro, chamada por Heidegger de Vorlaufen (adiantar). Esse adiantar-se possibilita ao Dasein compreender a si mesmo a partir dessa possibilidade mais própria. Ao compreender a si mesmo a partir desse seu poder-ser mais próprio, o Dasein é sacado do esquecimento de si no qual ele já sempre se encontra em meio aos entes que comparecem no mundo. Esse sair do esquecimento em que o Dasein retorna a si mesmo e dá conta do seu estado de lançado é o que Heidegger chama de Wiederholung (retomada), que é a modulação própria do vigor de ter sido (Gewesenheit). Nesta repetição, isto é, neste retorno a si, o Dasein deixa de compreender e interpretar a si mesmo a partir dos entes que estão à sua volta para, finalmente, perceber-se em seu estado de aberto e já sempre lançado. Isso significa que o outro e os demais entes em geral não mais perseveram no ser-para-amorte como a medida de referência do Dasein, não lhe restando diante disso outra opção além de tomar para si sua própria existência. Heidegger chama de Augenblick (instante) o arroubo desse reconhecimento de si não mais a partir do ente que o Dasein mesmo não é. $\mathrm{O}$ instante é, enquanto modulação própria do presente (Gegenwart), o susto do máximo estranhamento que retira o Dasein de sua familiaridade em meio à ocupação para com os entes no mundo circundante. 
O "antecipar-se", característico do futuro, explica a sua primazia frente ao modo de ser do Dasein enquanto lançado, ek-stático, pois o estado de lançado só pode configurar-se enquanto tal em razão de um projetar-se, de um lançar-se. Contudo, ainda não está claro como isso se reflete nas relações entre as outras ekstases. Resta-nos, portanto, examinar especificamente as ekstases do vigor de ter sido (Gewesenheit) e do presente (Gegenwart) para percebermos como elas se satisfazem desde a ekstase do futuro e, principalmente, verificar como se fundamentam nelas o passado e o presente no sentido vulgar. Isso deve mostrar-se claramente sem que nunca percamos de vista o fato de que a análise das ekstases não pode ocorrer isoladamente dentro do conceito de temporalidade.

\subsubsection{A temporalidade como unidades das ekstases: a ekstase do "vigor de ter sido" (Gewesenheit)}

DO MESMO MODO que a compreensão cotidiana do futuro enquanto um "agora ainda não presente" se assenta em um sentido mais originário, a compreensão mediana do passado enquanto um "agora não mais" também tem um fundamento inexpresso que a possibilita.

Já antecipamos que o "agora não mais", o "outrora", funda sua possibilidade na "retenção" (Behalten), que se caracteriza como a manutenção de algo que já aconteceu, isto é, é um trazer algo de volta à presentificação (Gegenwärtigen). A retenção, portanto, só é possível se o Dasein "mantém-se concomitantemente com aquilo que ele já tinha sido [was es schon gewesen ist]" (Heidegger, 2012a, p. 386). Com esse "manter-se", Heidegger nos diz que o passado (Gewesenheit), em seu sentido originário, não é algo que passa, algo do qual nos livramos, mas, por permanecer retido, é algo do qual o Dasein não escapa ${ }^{24}$.

É de se notar que Heidegger não usa a palavra alemã mais usual para se referir ao passado - a saber, Vergangenheit. A razão disso é o fato desta palavra vir do verbo vergehen, que significa 'passar', 'definhar', 'perecer', 'morrer' - em suma,

24 "Aquilo que nós tínhamos sido não passou no sentido de que poderíamos nos despir de nosso passado, tal como de resto costumamos dizer, como nos despimos de uma roupa. Assim como o ser-aí não pode escapar de sua morte, ele também não pode se livrar do seu passado" (Heidegger, 2012a, p. 386). 
o movimento de algo que ficou para trás, já consumado. Como já dito, não é esse o sentido que Heidegger quer fazer transparecer na ekstase do passado. Ao contrário, ele quer denotar o fato de que esse passado nunca cessa, nunca fica definitivamente para trás. Por isso, Heidegger escolhe a palavra Gewesenheit para demonstrar essa atuação sempre presente do passado. Gewesenheit é um termo cunhado desde gewesen (sido), particípio passado do verbo ser (sein). Gewesen deixa ecoar também a palavra Wesen (essência). É importante salientar isso na compreensão de Gewesenheit porque a "essência" é, justamente, o princípio de algo. É aquilo que tem de estar o tempo todo lá, desde o começo, para que algo seja o que é. A "essência" já deve ter sido e continuar sendo na medida em que essencializa algo. A essência (Wesen) é, portanto, aquilo que não passa. Por essa razão, as traduções das obras de Heidegger que contemplam o termo Gewesenheit tendem a tomá-lo por 'vigor de ter sido'. O "vigor" aponta algo que ainda vigora, que não ficou enterrado definitivamente no passado enquanto Vergangenheit. Mas como podemos entender esse comportamento fundamental da Gewesenheit?

Para entendermos o que está em jogo na Gewesenheit, é fundamental que lembremos o comportamento que está implicado na ekstase do futuro. Esta, conforme insistido, diz respeito ao "projetar" do Dasein, o "antecipar a si mesmo em suas possibilidades”. Tal antecipar, no entanto, é um antecipar que já sempre antecipou o Dasein em uma ou outra possibilidade. Isso significa que o Dasein já sempre se encontra em um estado de lançado. Estar já sempre lançado em uma possibilidade, no entanto, implica que o Dasein constantemente há sido uma tal ou qual possibilidade determinada. A ekstase (o para fora) do passado (Gewesenheit) indica que o Dasein já semprefoi, que ele é um "já sempre ter sido", que a projeção já sempre operou ${ }^{25}$. Por isso "o vigor de ter sido" (Gewesenheit) não diz respeito a um acontecimento que ficou encerrado no passado enquanto Vergangenheit e nem que seu vigor diga respeito a meras consequências presentes de ações que remontam a um passado que já não é mais (Vergangenheit). $\mathrm{O}$ "estado de lançado" que diz respeito a um "já sempre ter sido" indica, sobretudo, que a ekstase do passado (Gewesenheit) encontra-se sob a primazia do "lançar-se"

25 "Retendo ou esquecendo alguma coisa, o ser-aí sempre se relaciona de algum modo com aquilo que ele mesmo já era. Ele só é do modo como ele a cada vez faticamente é, de tal forma que ele já sempre a cada vez foi o ente que ele é" (Heidegger, 2012a, p. 385). 
do futuro. Com isso, pode-se dizer que "o vigor de ter sido [Gewesenheit] surge, de certo modo, do porvir [Zukunft]" (2008, p. 410). Tal primazia, obviamente, não deve ser entendida como uma anterioridade cronológica na qual haveria um evento sucessivo em que a Gewesenheit só apareça depois do futuro - já que o antecipar já sempre se antecipou de uma forma ou outra -, mas somente que a Gewesenheit demanda a antecipação mesma para sua efetivação. Perceba-se, portanto, que qualquer "separação" entre futuro (Zukunft) e passado (Gewesenheit) só pode minimamente ter sentido dentro de uma tentativa hermenêutica que busca explicar o fenômeno da temporalidade, mas que, de fato, tais ekstases já estão sempre mutuamente implicadas e são indissociáveis.

Por sua vez, o fato do "vigor de ter sido" (Gewesenheit) encontrar sua orientação a partir da ekstase do futuro - e, portanto, estar em consonância com a modulação inautêntica (Gewärtigen) ou autêntica (Vorlaufen) do futuro - traz como consequência que tal vigor também é capaz de temporalizar-se de dois modos. Heidegger (2006b) nos diz que o "vigor de ter sido" (Gewesenheit) apresenta-se de modo inautêntico enquanto "retenção" e "esquecimento" (Vergessenheit) (p. 339). Tal esquecimento configura-se quando o Dasein, ao não assumir sua possibilidade mais própria, não se apropria de seu passado no seu sempre já e toma-o como algo que ficou para trás, esquecendo-o. Novamente em face de suas ocupaçôes cotidianas do presente, o Dasein tende a ocultar o passado como algo que já não é mais aí, que já não é sempre já e passa a compreender a Gewesenheit como Vergangenheit. Desse modo, ao ocultar o seu passado, não se decidindo por ele, o Dasein esquece de si mesmo ${ }^{26}$, de seu poder-ser mais próprio e se confunde com a multiplicidade que o cerca. O esquecimento, enquanto modo impróprio do vigor de ter sido, está em uma relação unitária com a modulação imprópria do futuro, a expectação. Isso é assim porque na medida em que expectamos o

26 Há de se ressaltar, contudo, que o "lembrar-se" só é possível em razão do esquecimento. Em Ser e tempo, Heidegger postula: "no modo do esquecimento, o vigor de ter sido 'abre', primariamente, o horizonte em que a presença [Dasein], perdida na 'exterioridade' das ocupações, pode recordar-se" (2008, p. 425). Tal "lembrar", por sua vez, é o próprio exercício que Heidegger desenvolve em Ser e tempo. A prova disso está em perceber que o tema do esquecimento é o assunto que abre a obra. A pergunta pelo sentido do ser em Ser e tempo é direcionada a partir da denúncia do esquecimento do ser no qual já sempre nos movemos. Esse esquecimento está fundamentado na modulação inautêntica da ekstase do passado. 
nosso poder-ser a partir das coisas que nos cercam e com as quais nos ocupamos, acabamos por nos distrair e, consequentemente, caímos em esquecimento em relação à facticidade em jogo na Gewesenheit. Ao encobrir a facticidade que a Gewesenheit é, o Dasein cai em esquecimento em relação tanto ao seu poderser quanto ao próprio esquecimento. Isso quer dizer que o esquecimento não dá conta, não percebe a si mesmo. A consequência disso é que o esquecimento não permite uma saída a partir de si mesmo. É necessário que haja uma quebra, um corte $^{27}$ que proporcione ao Dasein um susto para com seu próprio poder-ser e o acolha enquanto tal. Somente diante de tal possibilidade o Dasein pode retomar a si mesmo. Assim como o adiantar (Vorlaufen) é a modulação autêntica do futuro, essa retomada (Wiederholung) é o modo como Heidegger (2006b) nomeia a temporalização fundamental da Gewesenheit (p. 339). Nela, o Dasein pode com vistas ao futuro (adiantando seu poder-ser) apropriar-se de seu passado (sempre já) enquanto presente vivo. A retomada tem a ver, assim, com um tomar a si mesmo de volta, isto é, com um descobrir-se em seu caráter de lançado e assumir-se enquanto tal ou, dito de outra forma, ir ao encontro do passado voltando-se para o futuro (Heidegger, 2012a, pp. 416 e ss).

\subsubsection{A temporalidade como unidades das ekstases: a ekstase do "presente" (Gegenwart)}

O “OUTRORA" E O "AINDA NÃO" fundam suas possibilidades nas autointerpretações de comportamento da expectação (Gewärtigen) e da retenção (Behalten). Estas, por sua vez, são respectivamente os modos impróprios das ekstases temporais do futuro (Zukunft) e do vigor de ter sido (Gewesenheit). Semelhantemente, o "agora" funda-se na presentificação (Gegenwärtigen), que corresponde ao modo inautêntico da ekstase do presente (Gegenwart). Portanto, o tempo expresso - o tempo do relógio - só encontra sua possibilidade no modo inautêntico da temporalidade do Dasein. Mas, como a presentificação (Gegenwärtigen) se manifesta enquanto possibilidade da ekstase do presente (Gegenwart)? Antes de buscar essa resposta, é bom reafirmar que o "presente" não é o mesmo que presentidade,

27 O corte é o corte da de-cisão (Entschlossenheit). Entschlossenheit enquanto Entschiedenheit. 
isto é, a presença no sentido de Anwesenheit ${ }^{28}$. Esta última diz respeito ao modo de ser dos entes que estão aí presentes à vista (Vorhandenheit); ao passo que o presente (Gegenwart) diz respeito a um comportamento desvelador que concerne somente ao Dasein. É em tal comportamento que o Dasein tem à vista o ente que está aí. No Gegenwart está fundado o deixar comparecer (Begegnenlassen) do ente que "está aî", possibilitando-o, então, estar presente (anwesend) ${ }^{29}$, isto é, "estar aî" de tal ou qual modo. Este "está aî" significa estar "presente à vista" (Vorhandenheit). Em tal comportamento, diz Heidegger (2012a), o Dasein "se comporta de maneira presentificante [gegenwärtigend] em relação a algo presente à vista [Vorhandenen] e mantém esse ente como algo presente [Anwesendes] em seu presente [Gegenwart]" (p. 387). Ao "manter o ente como algo presente [Anwesendes]", o Dasein se mantém junto ao ente que está aí, presente à vista. Tal "se-manter-junto-a" (Sichaufhalten bei) é o que Heidegger identifica como o essencial do presente $(\text { Gegenwart })^{30}$. O movimento ekstático do presente reside, portanto, no fato de que nele o Dasein é transportado (entrückt) "para junto de um outro ente" (2012a, p. 388). O movimento de ser transportado, "deslocado para junto”, está expresso, de certa forma, na própria palavra Gegenwärtigen. $\mathrm{O}$ vocábulo - Gegen-wärtigen - indica um movimento de ir de encontro (gegen-) a aquilo que se aguarda, se expecta (-warten). Tal indicação afirma também que a presentificação (Gegen-wärtigen) encontra sua atualização desde a expectação (Gewärtigen). Por encontrar sua atualização desde um modo inautêntico da ekstase do futuro, a presentificação (Gegenwärtigen) representa também uma modulação inautêntica do presente. A presentificação é a busca, o salto que tenta

28 "Presentidade constante" (ständige Anwesenheit) é a expressão que Heidegger emprega toda vez que quer se referir ao modo de ser daquilo que se encontra presente à vista, isto é, do ente que tem o modo de ser da Vorhandenheit (2012a, p. 387).

29 "Esse deixar vir ao encontro funda-se numa atualidade [Gegenwart]. A atualidade fornece o horizonte ekstático no qual o ente pode ser corporealmente vigente [anwesend]" (Heidegger, 2008, p. 433).

30 "O essencial do futuro reside no chegar-a-si [Auf-sich-zukommen], o essencial do sido no retorno-a [Zurück-zu] e o essencial do presente no se-manter-junto-a [Sichaufhalten bei] isto é, no ser-junto-a" (Heidegger, 2012a, p. 387). 
sair da expectação $0^{31}$ pela sua atualização: ela busca não estar mais à espera, evadirse (entlaufen) do aguardo. Entretanto, quando ela o faz - salta fora do estar à espera -, ela não se entrega a si mesma de modo a apartar-se completamente da expectação. "Não se entregar a si mesma" significa aqui que a presentificação tende a não se deter diante da "coisa" em seu estado presente - antes, ela tende a satisfazer-se com uma breve "espiada" sobre essa mesma "coisa" e já dirigir-se para a seguinte. É esse comportamento da presentificação, diz Heidegger (2006b), que leva o Dasein à ansiedade (Unverweilen), típica da curiosidade (p. 347), e, consequentemente, à distração. $\mathrm{O}$ saltar fora da presentificação que fundamenta a curiosidade está sempre visando ao próximo, àquilo que vem depois e depois e, por isso, não se aparta da expectação, mas apenas transforma este "estar à espera" da expectação em um "estar à espera que salta para depois" (nachspringenden) 32 . Em meio ao saltar fora que visa sempre ao depois e depois, o Dasein é incapaz de apreender o futuro enquanto um voltar em direção a si mesmo, um adiantar a si mesmo em seu poder ser, em seu ser possível e, consequentemente, de apropriarse de seu passado. Ao contrário, distraindo-se o Dasein esquece de si mesmo e foge de si entre uma coisa e outra.

Heidegger (2008) também nos diz em Ser e tempo que a presentificação que fundamenta a curiosidade, a ansiedade da distração, é "o fenômeno que mais explicitamente se opõe ao instante (Augenblick)” (p. 434). Enquanto a presentificação aponta para a possibilidade da compreensão imprópria da ekstase do presente (Gegenwart), o instante representa a modulação autêntica, inexpressa de tal ekstase.

31 "A curiosidade constitui-se por meio de uma presentificação insustentável que, apenas presentificando, procura constantemente evadir-se do estar à espera, no qual está sustentada de modo insustentável. O presente 'salta fora' do correspondente estar à espera no sentido mencionado do evadir-se” (2006b, p. 347; tradução nossa). [„Die Neugier wird konstituiert durch ein ungehaltenes Gegenwärtigen, das, nur gegenwärtigend, damit ständig dem Gewärtigen, darin es doch ungehalten »gehalten « ist, zu entlaufen sucht. Die Gegenwart »entspringt« dem zugehörigen Gewärtigen in dem betonten Sinne des Entlaufens."].

32 "A modificação ekstática do estar à espera por meio da presentificação que salta fora para um saltar para depois é a condição temporal e existencial da possibilidade da distração" (2006b, p. 347; tradução nossa). [„Die ekstatische Modifizierung des Gewärtigens durch das entspringende Gegenwärtigen zu einem nachspringenden ist die existenzial-zeitliche Bedingung der Möglichkeit der Zerstreunng."] 
Mas o que é um instante? Quanto tempo dura um instante? Um instante não dura tempo algum porque ele não está no tempo. Ele não é "algo" que se deixa captar no fluxo contínuo do tempo e se pode contar. Ele é, antes, como o soco seco de um estalo que quando se quer contar, "pegar", já foi. Para entender o que está em jogo no instante e sua atuação como modo próprio do presente, talvez seja interessante voltar os nossos olhos à etimologia da própria palavra alemã usada por Heidegger, Augenblick. Von Falkenhayn (2003) nos diz que:

A origem da palavra 'Augenblick' é mais simples. 'Ougenblic' significa no alto alemão médio, antes de tudo, a 'visão do olho' [Blick der Augen]. O 'Augenblick', no entanto, não caracteriza um olhar errante, mas o que captura uma visão temporalmente curta dentro da abertura e do fechamento do olho. No século 13, a palavra 'Augenbilck', em alemão, também recebe um significado temporal e diz respeito a um curto período de tempo (p. 26; tradução nossa) ${ }^{33}$.

Augenblick pode, então, ser traduzido como um 'piscar de olho'. Mas, mais do que um mero piscar de olho - que fornece a impressão do "não se poder contar" do instante -, Augenblick diz respeito a um ver que de um só golpe apreende toda uma situação $0^{34}$. Diríamos isso em português com as palavras "sacada" ou "lampejo". Mas, que situação é essa que o Dasein capta no instante? Ele capta seu poder ser mais próprio. Ao contrário da presentificação que desvia o Dasein de si mesmo por meio da distração em meio às coisas que o circundam - de modo a fazer com que o seu vigor de ter sido vigore enquanto esquecimento e seu futuro enquanto expectação -, o instante, enquanto modulação autêntica do presente, é um deslocamento (ekstático) decidido do Dasein para o interior de seu poder ser mais próprio. Acerca disso, diz Heidegger (2008): “[O instante] é a retração [Entrückung] da presença [Dasein] decidida, mas mantida na decisão, ao que de possibilidade e circunstâncias passíveis de ocupação vem ao encontro na situação" (p. 424).

33 „Die Herkunft des Wortes 'Augenblick' ist einfacher. 'Ougenblic' bedeutet im Mittelhochdeutschen zunächst der 'Blick der Augen'. Der 'Augenblick' kennzeichnet jedoch nicht einen umberschweifenden Blick, sondern das, was ein zeitlich kurzer Blick innerbalb des Aufschlagens und Schließens des Auges sehend erfaßt. Im 13. Jahrhundert erhält das Wort 'Augenblick' im Deutschen auch eine zeitliche Bedeutung und steht für eine kurze Zeitspanne."

34 Sobre a etimologia de Augenblick e mais estudos sobre o tema, vide, sobretudo, von Falkenhayn (2003, pp. 25, 129-220) e Másmela (2000, pp. 155-210). 
Fica claro nessa passagem que "decisão" e "instante" caminham essencialmente juntos. Na decisão (Entschlossenheit) está em jogo uma apropriação do Dasein acerca de seu estado de lançado - e, com isso, um adiantar-se ao seu poder ser mais próprio e uma retomada apropriadora de seu passado. Por mover-se nesse caráter especificamente próprio da ekstase, pode-se dizer que a "decisão tem a sua própria temporalidade" (2012a, p. 417) - ou, em outras palavras, que a decisão é ela mesma o modo específico como o Dasein abre a si mesmo para seu estado de aberto (Erschlossenheit $)^{35}$. Tal é o modo específico da existência própria (eigentliche Existenz). Heidegger (2012a), em Os problemas fundamentais da fenomenologia, esclarece com precisão o que é a decisão enquanto o modo específico da existência própria:

A existência própria, isto é, tal existência do ser-aí, de acordo com a qual o ser-aí ele mesmo é em e a partir de sua possibilidade mais própria, tomada por ele mesmo, é por nós denominada decisão. Essa decisão tem a sua própria temporalidade. [...] Se o existir próprio, a decisão, funda-se em um modo determinado da temporalidade, então pertence à decisão um presente determinado. Enquanto fenômeno ekstático-horizontal, o presente significa presentificação de... Na decisão, o ser-aí se compreende a partir do seu poderser mais próprio. [...] No advir a si, o ser-aí também já se assumiu como o ente

35 Erschlossenheit (estado de aberto) e Entschlossenheit (decisão) também caminham juntos. Ambas as palavras vêm do verbo schliessen, que tem o sentido de 'fechar', 'encerrar,' 'trancar', 'concluir'. O prefixo ent-, que compõe Entschlossenheit, indica em geral uma oposição, uma separação. Por isso, o verbo entschliessen, em seus primórdios, significava 'abrir', 'destrancar' tal como erschliessen que forma Erschlossenheit (estado de aberto). Heidegger apropria-se desse sentido de abertura que ecoava inicialmente em entschliessen para indicar que Entschlossenheit diz respeito também a uma abertura, não a um modo qualquer dela, mas ao seu modo autêntico. Inwood (2002), citando o Dictionary of German Synonyms de R. B. Farrell (1977), diz que a partir do "século XVI o reflexivo sich entschliessen passou, no entanto, a significar 'decidir, tomar uma decisão', i.e., 'abrir a mente, esclarecer, definir os pensamentos"' (p. 33). Heidegger também faz uso desse sentido e, por isso, talvez o melhor modo de pensar a decisão (Entschlossenheit) seja através da palavra sinônima Entschiedenheit. Essa palavra é especialmente boa para explicar o fenômeno da decisão porque ela denota claramente um sentido de 'corte' que vem do verbo scheiden. A partir dessa ideia, fica indicado que a decisão (Entschlossenheit) produz um corte na corrente disposição, na conjuntura em que as coisas já se encontram previamente dadas e permite que o Dasein venha a si mesmo repentinamente. Ao romper com este "estado de coisa" no qual o Dasein já está sempre lançado, a decisão abre uma nova possibilidade na qual o Dasein é jogado diante de seu próprio poder-ser. 
que ele a cada vez já tinha sido. Na decisão, isto é, no compreender-se a partir de seu poder-ser mais próprio - neste advir a si mesmo a partir da possibilidade mais própria, o ser-aí retorna ao que ele é, assumindo-se como o ente que ele é. No retorno a si mesmo, ele se repete com tudo aquilo que ele é e se lança para o interior de seu poder-ser mais próprio tomado (pp. 416-417).

Heidegger (2008) expõe que convém à existência própria do Dasein a temporalidade autêntica, inexpressa. A decisão é o que abre ao Dasein o modo específico da existência própria. Radicalmente falando, não há diferença entre estar na decisão e existir propriamente. Em contraposição à existência própria do Dasein, está a impropriedade, que também detém um modo da temporalidade que lhe é condizente. Esse modo, como já falamos, está em sintonia com a compreensão vulgar do tempo que se dá desde a unidade da presentificação, da expectação e da retenção/esquecimento. A impropriedade marca o modo de ser do Dasein no qual ele vive seu dia a dia, é a cotidianidade do viver. Tal cotidianidade perdura sobre o Dasein toda a sua vida e fornece as estruturas da vida comum que nos permitem viver o corrente dia após dia. Na "monotonia", que marca esse dia após dia e nivela nossa compreensão de mundo e de nós mesmos em um "mesmo tom", expectamos o amanhã como o "eternamente ontem" (p. 461) e tomamos todos os dias como iguais. Tomamos, também, a nós mesmos no mesmo tom dos entes que nos circundam. Assim, entendemos que "estamos aí" do mesmo modo como todas as coisas aí estão. Contudo, devemos lembrar que a cotidianidade é um modo de ser constitutivo do Dasein, pertence-lhe essencialmente, é parte constitutiva da sua existência, o que significa que o Dasein jamais se livra dela. Ela não é um "mero aspecto" que ora se dá e ora não. Ela já está dada aí o tempo todo na facticidade do Dasein em meio aos entes. É nela, na decadência, que está dado o modo habitual como o Dasein é em meio aos entes que estão no mundo. Mas, embora não possamos nos desembaraçar da cotidianidade, a existência, diz Heidegger (2008), "pode amestrar, embora nunca apagar, o cotidiano no instante e, sem dúvida, apenas 'por um instante”' (p. 461). E por quê? Porque o instante é o tempo da decisão. É o corte, a ruptura para com a dispersão da cotidianidade, com a ocupação corriqueira que distrai o Dasein de si mesmo ${ }^{36}$.

36 O que obviamente não significa uma eliminação da cotidianidade, mas, como diz Heidegger (2008), um "tornar-se mestre" (meistern) (p. 461), um assenhorear-se dela. É nisso que consiste o corte da decisão que se antecipa a esse estado de lançado. Do mesmo modo, podemos falar da 
Perceba-se, portanto, que a temporalidade, na sua modulação própria, é possibilitadora da existência própria do Dasein. Nas palavras de Haar (1990): "A temporalidade originária temporaliza, quer dizer, possibilita radicalmente todos os modos de ser do Dasein, confere sentido a todos os existenciais (a compreensão, a disposição afetiva e a decaída), mas sobretudo torna possível o autêntico e o inautêntico" (p. 61).

A existência própria nada mais é do que o Dasein compreendendo a si mesmo a partir de seu poder-ser mais próprio. Tal possibilidade é dada por uma ruptura na qual o Dasein é mantido (presente) no adiantar a si mesmo (futuro) que assume retomando o que ele já tinha sido (passado). A ruptura é o arrebatamento do instante da decisão. Por promover tal deslocamento, o arroubo do instante é essencialmente ekstático.

O modo como compreensão do instante nos é apresentada, bem como sua relação essencial com a decisão e com a propriedade, permite que nos afastemos de uma postura interpretativa relativamente comum dos textos de Heidegger, a saber, que a propriedade do Dasein trata-se apenas de um "tomar consciência de sua impropriedade”. Sembera (2007), por exemplo, nos diz que: "a autenticidade consiste tanto no reconhecimento [acknowledgement] de que inautenticidade é uma parte inerradicável da experiência humana quanto em uma resposta autêntica a esse fato inescapável” (p. 221; tradução nossa) ${ }^{37}$. É certo que a análise de Sembera sobre a autenticidade, a existência própria, não se esgota no simplismo da citação acima. Contudo, ela revela uma tendência, a saber, que a autenticidade pode ser compreendida como uma "análise", "reflexão crítica" ou "reconhecimento" da impropriedade. Ora, a autentidade, que corresponde à temporalidade autêntica e, portanto, está no tempo do instante, não olha para a impropriedade, não tem "tempo" de se deter sobre ela. No instante da autenticidade, o Dasein só tem vista a sua possibilidade mais própria, ser-para-a-morte. Toda análise, reflexão teórica ou "reconhecimento" sobre a impropriedade são, sim, decorrentes

compreensão imprópria do tempo. Nós nunca nos livramos de pensar o tempo como uma sucessão ininterrupta de "agoras". E nem é bom que nos livremos disso. O problema está em tomar essa possibilidade como sua única possibilidade ou como sua possibilidade mais própria.

37 "Authenticity, therefore, cannot consist in excising inauthenticity from the sphere of human experience. Rather, authenticity consists both in the acknowledgement that inauthenticity is an inerad-icable part of human experience and an authentic response to this inescapable fact." 
do instante da decisão, mas só ocorrem quando voltamos a nos mover no modo da impropriedade. O Dasein que analisa e reconhece já é "deslocado para junto" (Gegenwärtigen) de algo ou de um assunto e, portanto, volta-se a mover na presentificação. Ele já não se encontra mais no "golpe de vista" (Augenblick), ao contrário, justamente por estar fora do golpe, é que ele pode analisar o próprio golpe e seus desdobramentos.

Pois bem, a exposição feita até aqui cumpriu observar que as ekstases do futuro (Zukunft), do vigor de ter sido (Gewesenheit) e do presente (Gegenwart) deixam-se antever em uma unidade na temporalidade. Não nos interessa, de modo algum, pensar a temporalidade a partir de um esquematismo em que ela é decomposta em meras estruturas formais. Ela mesma não se permite pensar de tal forma - ao contrário, ela só se deixa apreender enquanto um fenômeno originário unitário que vincula indissociavelmente as ekstases. Como vimos, embora o essencial de cada uma das ekstases da temporalidade resida respectivamente nos sentidos específicos do chegar-a-si, do retorno-a e do se-manter-junto-a, deve-se ressaltar que tudo isso se dá em um único movimento, caracterizado essen-

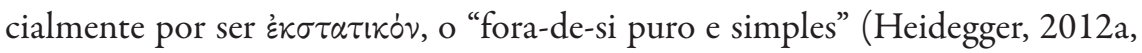
p. 388). Perceba-se, contudo, que no movimento ekstático da temporalidade vigora tanto a unidade da possibilidade própria de cada ekstase (adiantar-se, retomada e instante) quanto a unidade de sua modulação imprópria (expectação, esquecimento e presentificação), uma vez que, sendo a temporalidade ekstática, ela já está sempre abrindo o Dasein nesta ou naquela possibilidade ${ }^{38}$.

38 Não há na literatura secundária diferenças interpretativas significativas no que diz respeito ao modo como Heidegger organiza a estrutura da temporalidade. De modo geral, os comentadores apenas acompanham os argumentos já bem desenhados por Heidegger na formulação da estrutura da temporalidade, diferenciando-se somente na ênfase dada a uma ou outra ekstase, em especial às modulaçôes próprias do futuro (Vorlaufen) e do presente (Augenblick). É comum, também, encontrar obras que relacionam a estrutura da temporalidade com o pensamento de outros filósofos. Contudo, tais obras igualmente não apontam novidades interpretativas quanto à estrutura mesma da temporalidade. De certa forma, isso explica a ausência de um debate interpretativo da estrutura da temporalidade no presente texto. As diferenças interpretativas, no entanto, ganham musculatura quando a estrutura da temporalidade pensada pelo jovem Heidegger deixa de ser pensada em si mesma e começa a ser analisada a partir do evento da virada de seu pensamento. O que significa tal virada e as consequências que ela traz para a questão do tempo são temas que trazem discussões expressivas e diferenças importantes entre os intérpretes, sobretudo quanto ao caráter horizontal das ekstases temporais desenvolvido em Ser e tempo. Por mais que tais discussões interpretativas 
Por sua vez, dizer que "a temporalidade, por ser ekstática, está sempre abrindo o Dasein" significa que a temporalidade, na medida em que é o "fora-de-si", pertence-lhe essencialmente uma abertura. Todo "para-fora" requer uma abertura. Essa abertura é, ela mesma, uma amplitude propiciada pelo "para-fora”, isto é, pelo direcionamento que concerne ao "fora-de-si". Tal amplitude é o que Heidegger chama de "horizonte" 39 da temporalidade. Por ser a temporalidade mesma esse "para-fora" propiciador da abertura, consequentemente, todo "pôr em aberto", todo "ex-por", todo "fazer ver" encontra sua disposição na temporalidade. A consequência fundamental disso é que a temporalidade é a condição de possibilidade de toda compreensão de ser, de todo vir à tona e, portanto, de toda manifestação do ente, do estar aí do ente, de sua presentidade constante (Anwesenheit). É o presente (Gegenwart), em seu presentificar (Gegenwärtigen), que possibilita o estar aí presente do ente (Vorhandenheit). Tal afirmação não é pouco significativa na obra de Heidegger, pois ela nos abre uma importante via de investigação acerca do ser. Isso se evidencia quando se conclui que se a presentidade (Anwesenheit) é a determinação do ser dos entes, então o presente (Gegenwart), enquanto desvelamento que traz à tona o ente em sua presentidade, é a determinação mais originária do ser. A consequência evidente disso é que o tempo é o elemento que doa sentido a toda compreensão de ser. É a partir disso que o tempo pode se revelar na obra de Heidegger como o horizonte de toda compreensão de ser.

A relação direta entre a temporalidade e a presentidade constante (Anwesenheit), contudo, não está suficientemente clara desde o exposto até aqui. Cabe, portanto, melhor investigar como a temporalidade possibilita a compreensão de ser do ente que está aí presente à vista (Vorhandenen).

sejam profundamente ricas, elas não convêm aos limites do presente trabalho. A circunscrição de nossa investigação não alcança o período dos textos da maturidade de Heidegger e, portanto, não justifica que entremos nos debates interpretativos sobre sua influência da virada de seu pensamento na questão da temporalidade. Nosso objetivo é expor como a temporalidade, enquanto sentido do ser do Dasein, possibilita a compreensão dos entes como presentidade (Anwesenheit). Para tanto, é suficiente o recurso a uma explicação prévia da unidade da temporalidade em suas modulações possíveis. Sobre os debates de como a temporalidade passará a ser interpretada nas obras tardias de Heidegger, vale conferir as indicações dadas na nota 3.

39 "O horizonte é a amplitude aberta, para o interior da qual o deslocamento enquanto tal está fora de si. O deslocamento abre e mantém aberto esse horizonte” (Heidegger, 2012a, p. 389). 


\section{Temporalidade e presentidade constante}

AtÉ aQUi, falamos DA TEMPORALIDAde direcionando-a a partir da compreensão do modo de ser autêntico ou inautêntico do Dasein. Todavia, temos de pensar agora essa temporalidade com vistas à compreensão de ser do ente que está simplesmente presente aí (Vorbandenen) e que, portanto, carrega o modo de ser da presentidade constante. Heidegger (2012a) também trata desse assunto em Os problemas fundamentais da fenomenologia (\$21), afirmando, como não poderia deixar de ser, que a temporalidade é "a condição de possibilidade da compreensão de ser, que compreende o ente no sentido do [...] presente à vista [Vorhandenen]" (p. 423). A partir da unidade articulada das ekstases, que configura o modo de ser do Dasein, é possível visualizar a compreensão de ser que diz respeito ao ente que se encontra aí presente - em outras palavras, conceber a temporalidade como horizonte da compreensão de ser.

Todavia, antes mesmo de lançarmos qualquer consideração direta acerca da relação entre a temporalidade e a presentidade, é importante lembrar que essa relação já está dada na própria relação da temporalidade com o modo de ser do Dasein. Isso porque se a temporalidade é o caráter fundamental do Dasein, isto é, aquilo que possibilita seu caráter ekstático-transcendental - o para-fora que dita não só a sua existencialidade, mas que também configura o horizonte aberto no qual os entes podem vir ao encontro em uma rede articulada de sentido -, a própria interpretação do modo de ser do Dasein com vistas à temporalidade já propicia a interpretação do ser do ente que é aí presente. Portanto, somente porque o Dasein é este horizonte ekstático que articula sentido, os entes podem vir ao encontro e ser desvelados como entes presentes à vista ou em face de sua instrumentalidade. Esse horizonte, portanto, é condição de possibilidade para a compreensão de ser do ente que é aí presente (Vorbandenen). Sem dúvida, podemos nos embasar nessa afirmação para consolidar a relação entre o ente que tem o caráter de ser da presentidade constante (Anwesenheit) e a temporalidade. De modo geral, a explicação que von Herrmann traça em seu $A$ segunda metade de Ser e Tempo não é muito distante disso. Na breve passagem em que se ocupara do problema da interpretação temporal do ente que está aí (Vorhandenen), von Herrmann basicamente se limita a dizer que 
o ente cujo ser é projetado como o que está aí presente [Vorhandenen] para o horizonte do tempo originário vem ao encontro do ser-aí [Dasein] no trato ocupado [besorgender Umgang]. Esse trato tem ele mesmo uma temporalidade típica, a presentificação que retém expectando [das gewärtigend-behaltende Gegenwärtigen] (1997, p. 54; tradução nossa) ${ }^{40}$.

Ele alerta, contudo, que não é essa temporalidade (imprópria), mas a modalidade originária ${ }^{41} \mathrm{da}$ temporização da temporalidade (futuro, vigor de ter sido e presente) - que possibilita a compreensão de ser - é a que descobre o estar aí presente do ente (1997, p. 54). Então, conclui afirmando que

a ekstase do presente projeta, em unidade com as ekstases do futuro e do vigor de ter sido, o ente que está aí presente [Vorhandenen] enquanto tal para o horizonte da praesentia. $\mathrm{O}$ ser do ente que vem ao encontro intramundanamente é compreendido temporalmente na medida em que é projetado presencialmente (1997, pp. 54-55; tradução nossa) ${ }^{42}$.

A explicação de von Herrmann é correta, embora, bastante tísica. Tal qual a explicação que adiantamos, o argumento, de modo geral, recorre ao fato de que a temporalidade ekstática-horizontal na medida em que é origem da compreensão de ser do Dasein, de sua transcendência, é o que possibilita que algo venha ao encontro do Dasein como um fazer-se presente. É possível, no entanto, estendermos um pouco além os argumentos presentes nos Problemas fundamentais da fenomenologia a fim de conseguirmos expor como, de fato, a temporalidade atua no ente que está aí presente.

40 "el ente cuyo ser es proyectado como estar-a-la-mano hacia el horizonte del tiempo originario viene al encuentro del ahí-ser [Dasein] en el trato que este tiene con él al-cuidado-de-hacer-por-la-vida [besorgender Umgang]. Este trato tiene él mismo una temporalidad propia, el hacer-presente que retiene expectante [das gewärtigend-behaltende Gegenwärtigen]"

41 Von Herrmann não está se referindo aqui diretamente à modulação própria da temporalidade: adiantar-se, retomada e instante.

42 "el éxstasis del presente proyecta, en unidad con los éxstasis del porvenir y del haber-sido, el estar-ala-mano en cuanto tal hacia el horizonte de la praesentia. El ser del ente que viene al encuentro intramundamente es comprendido temporaliter en la medida en que es proyectado presencialmente". 


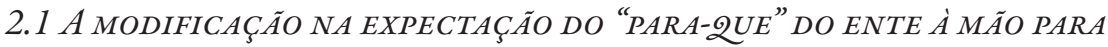 O "ACERCA-DE-2UE" DO ENTE PRESENTE À VISTA COMO EXPOSIÇÃO DO FUNDAMENTO DA PRESENTIDADE NA TEMPORALIDADE}

HeIdegger (2012A) NOS LEMbRA QUE, na maioria das vezes, não lidamos de modo imediato com o ente que tem o modo de ser do que está aí simplesmente presente (Vorbandenheit), mas que operamos cotidianamente com o ente que se apresenta no modo de ser da instrumentalidade (Zubandenheit). Significa que na lida com o ente, por exemplo, com o lápis, não percebemos ou focamos primeiramente no lápis enquanto tal, isoladamente, mas no contexto utensiliar em que o lápis se mostra. De fato, sequer reparamos no lápis; nossa percepção é, antes, totalmente orientada pela compreensão prévia do contexto de uso desse instrumento que nos direciona em seu "para-que". Somente porque esse contexto de uso já está dado o ente pode aparecer como determinado utensílio, em seu caráter instrumental (p. 424). Heidegger nos diz que um ente "não é o que e como ele é" (p. 425) para só depois receber uma utilidade, um "para-que”. Em um exemplo bem simples, poderíamos dizer que eu ando, não porque tenho pernas, mas só posso ter pernas porque o "andar" já me foi dado. É o "para andar" que diz o que são pernas. Sem o "para andar" não faz sentido algo como "perna". Do mesmo modo, é o "para escrever” que diz o que é um lápis, uma caneta. É o "para-que" que diz o que e como o utensílio é. O "para-que", continua Heidegger, indica a compreensão prévia de uma referência conformativa, isto é, de uma conformidade (Bewandtnis) ${ }^{43} \mathrm{em}$ que o utensílio pode vir à tona. O "para-que" é,

43 O termo Bewandtnis (arranjo, condição respectiva) não se refere a outra coisa senão o modo de ser do ente que se encontra à mão, isto é, do utensílio, do manual. Bewandtnis é, portanto, a manualidade (Zuhandenhei) que indica que o utensílio já se encontra sempre em uma condição respectiva com os outros entes, o que significa que, segundo seu modo de ser, um utensílio jamais pode ser entendido de modo isolado ou particular. Ele já está sempre e só vem à tona por carregar em seu modo de ser essa condição respectiva (Bewandtnis) com os outros entes. Poderíamos também traduzir Bewandtnis por 'arranjo'. Isso fica claro em algumas expressões próprias do alemão como es sich bewenden lassen - que significa 'deixar (algo) se virar sozinho', 'deixar algo ser como é,' 'deixar algo se arranjar - e es hat seine eigene Bewandtnis, que diz que '(algo) tem sua condição própria,' 'seu próprio arranjo'. A tradução de Bewandtnis por 'conformidade', tal como levada a cabo na tradução aqui utilizada, pode trazer alguns prejuízos, pois pode levar a entender, especialmente em bewenden lassen, que tratar-se-ia de uma ação do Dasein. Esse não é o caso. Como já insistido, Bewandtnis designa o modo de ser do ente que está à mão, do utensílio em sua relação com os demais utensílios. 
por sua vez, o que expectamos quando da utilização do utensílio e com o qual este se deixa conformar. Tal deixar conformar-se, no entanto, implica também retermos o "para-que" como aquilo "com-o-que" se tem em vista o utensílio. Só compreendemos o utensílio, portanto, quando, no expectar do "para-que", retemos este enquanto o "com-o-que" que se tem em vista no uso, possibilitando que o utensílio se mostre em sua referência conformativa. Em tal "mostrar-se na unidade ekstática expectante e retentora” é possibilitada a presentificação determinada de um utensílio. Isso significa que o utensílio só vem à tona, vem a um presente (Gegen-wart), na condição respectiva que o antecipa, isto é, em sua referência conformativa (Heidegger, 2012a, p. 426). Contudo, isso só nos expõe a temporalidade que diz respeito à ocupação com o ente que encontra seu modo de ser em uma referência conformativa, isto é, o utensílio (zuhandene Zeug). Mas como isso nos orienta a pensar a atuação da temporalidade, não quanto ao modo de ser do utensílio (Zuhandenheit), mas quanto ao modo de ser do ente que se traduz enquanto presentidade constante, o simplesmente dado? Com o que foi dito, indicou-se apenas que o compreender da conformidade (Bewandtnis), que possibilita o comparecimento do utensílio em seu "para-que", é constituída temporalmente.

Pensar o caráter temporal do ente que tem o modo de ser da presentidade constante, no entanto, perpassa necessariamente a análise temporal da lida com o manual, com o utensílio, o que fica claro, sobretudo, a partir da análise empreendida por Heidegger no $\$ 69$ de Ser e tempo. Nesse trecho da obra, em especial na alínea $b$, fica dado que a relação entre o tempo e o modo de ser da presentidade deixa-se evidenciar no "sentido temporal em que a ocupação, guiada pela circunvisão [umsichtigen Besorgens], se modifica em descoberta teórica do que é simplesmente dado [Vorhandenen]" (2008, p. 445). Mas o que isso quer dizer exatamente? É necessário esclarecer antes o que significa esse “ocupar-se" (Besorgen).

Heidegger (2008) cunha esse termo em Ser e tempo para designar a lida do Dasein com as coisas. Todo "produzir alguma coisa, cultivar e cuidar, usar, abandonar e deixar perder-se, empreender, impor, pesquisar, interrogar, contemplar, discutir, determinar..." (p. 95), todos esses modos do Dasein se relacionar com

Agora, quando o remetimento (Verweisung) finalmente alcança e toca a existência do Dasein, o termo que Heidegger passa a utilizar é significancia (Bedeutsambeit) (2008, \$18, pp. 133-139). 
as coisas têm o modo de ser da ocupação (Besorgen). Essa lida, por sua vez, é orientada não por um conhecimento teórico ou por uma contemplação constatadora de propriedades, mas por aquilo que Heidegger chama de "circunvisão" (Umsicht), que não é mais do que um "ter em vista o que está dado em volta". "Ter em vista”, em sua visão de conjunto, abarca de modo usual - isto é, não teórico "o material, o usuário, o uso, a obra, em todas as suas ordens" (Schuback apud Heidegger, 2008, p. 566) e dirige o manejo com o ente que está dado à mão. Poderíamos dizer que "circunvisão" (Umsicht) é o evidente na ocupação com o ente no mundo. Ademais, que a ocupação seja um "modo de ser" deve significar que ela é um termo ontológico que indica uma determinada possibilidade de ser. Essa possibilidade da ocupação é própria, isto é, típica, do Dasein $^{44}$ e diz respeito ao modo como ele é em relação às coisas. Mas, como já antecipamos, na ocupação - isto é, na lida com o ente - nós não lidamos primeiramente com o ente que tem o modo de ser do que está aí simplesmente presente, da presentidade (Vorhandenheit). Na ocupação lidamos, sobretudo, com aquilo que é utensílio, instrumento, com o ente que tem o modo de ser do manual (Zuhandenheit) ${ }^{45}$. Poder-se-ia pensar, então, que a interpretação do sentido temporal da transformação da ocupação circunspectiva em descobrimento do ente que está simplesmente aí presente à vista se configuraria por uma abstinência de todo caráter utilitário da ocupação. O caráter determinante do ente que está simplesmente aí presente à vista seria, então, a total ausência da praxis (Heidegger, 2008, p. 446). Mas isso, por si, não é suficiente. Essa ocupação deve também modificar-se em uma "percepção contemplativa" "'. Se isso é assim, então pensar o sentido temporal do ente que é simplesmente presente à vista deve passar pela consideração da

44 Que a ocupação seja uma possibilidade própria, isto é, constitutiva do Dasein, significa dizer que ela é um existencial.

45 Contudo, deve-se insistir que o utensílio não é a causa da ocupação. Essa, enquanto modo de ser do Dasein, não surge desde uma "atuação" do utensílio e nem está orientada a partir de um utensílio particular. O uso, como possibilidade da ocupação, está antes orientado, como já dito, pelo contexto utensiliar.

46 Isso não deve significar, contudo, a possibilidade de qualquer investigação ser tomada como algo puramente teorético. Heidegger nos lembra que "mesmo a elaboração mais 'abstrata' de problemas e a fixação do que foi obtido manipulam instrumentos de escrever, por exemplo” (2008, p. 446). 
modificação da compreensão de ser que converte o utensílio em ente simplesmente presente à vista (Vorhanden). Para ilustrar essa modificação, Heidegger dá o exemplo de que no uso do martelo podemos dizer "o martelo é pesado". Com essa frase, podemos nos referir ou que o martelo é de difícil uso - e, com isso, nos mantermos ainda completamente inseridos em uma reflexão do para-que, do uso do martelo - ou podemos simplesmente aludir o fato de que o martelo - que já foi circunspectivamente aberto e conhecido como martelo - tem peso, isto é, tem a qualidade de ser pesado por possuir massa e sofrer atração gravitacional. Quando dizemos que "o martelo é pesado" neste último sentido, diz Heidegger (2008), já não nos orientamos mais pela expectação do para-que que possibilita a presentificação determinada de um utensílio (pp. 449-450). O martelo, em tal caso, deixa de ser visto como utensílio, não mais é pensado como demasiadamente pesado para o seu "para-que", como "pesado para alguma tarefa", mas é agora visto no seu caráter geral enquanto "ente que possui massa”. Há aqui um "novo modo de ver", uma modificação da compreensão de ser do utensílio que agora passa a ser compreendido como um ente em seu estar aí presente à vista. Percebase que o determinante nessa modificação não é tanto o prescindir do caráter utensiliar do ente à mão, mas a configuração de uma nova perspectiva, de uma nova visão acerca do ente. Essa nova visão é possibilitada, por sua vez, por uma modificação da ekstase da expectação. Como assim? Se o utensílio presentifica-se enquanto tal ou qual utensílio em razão da expectação de seu "para-que", o ente simplesmente presente aí à vista só pode vir à tona se minha expectação for orientada, não mais diretamente pelo "para-que" de uma condição respectiva, mas de acordo com o exemplo do martelo, segundo um "acerca-de-que" eu falo. Somente quando a expectação antecipa o ente e o retém enquanto um "núcleo de propriedades", o ente presente à vista pode presentificar-se no modo da presentidade constante. Assim, fica claro que o que se modifica nesta conversão é a compreensão do modo de ser do ente. Tal modificação acarreta, por sua vez, uma modificação no "como" da presentificação do ente. A presentificação do ente presente à vista não se afigura mais enquanto uma unidade com a expectação de uma possibilidade de uso, de um "para-que" e nem na retenção deste "para-que" como aquilo "com-o-que" se tem em vista o utensílio. Embora o ente presente à vista não mais seja expectado em prol de seu "para-que" possível, a presentificação deste ente não é senão uma transformação do ocupar-se circunspectivamente descobridor que fornece as 
bases possíveis da modificação da compreensão de ser que o possibilita. É condição necessária para essa transformação que o mundo já se tenha aberto e que os entes já se tenham articulado em sua condição respectiva (Bewandtnis). O caráter temporal que possibilita o manual já é, portanto, pressuposto para que haja a presentificação do ente presente à vista (Vorbandenen). É necessário que o martelo já se tenha feito manifesto antes em seu caráter utensiliar para que então possa sofrer uma modificação que o "suspenda" de seu contexto utensiliar e o permita vir à tona enquanto um "acerca de que se fala" ao qual posso atribuir um predicado. Há aí uma mudança significativa no modo de ser do ente ${ }^{47}$, que passa agora a assumir o caráter da presentidade (Vorhandenheit). Quando tiro o martelo da caixa de ferramentas para pregar um prego que há de sustentar um quadro, o martelo nunca é um mero "isto" ou "aquilo", mas está antes totalmente entregue ao "paraque" de sua condição respectiva (Bewandtnis). Mas quando olho para o martelo - e necessariamente "suspendo" o seu martelar - ele deixa de ser visto e pensado na relação com o prego, com a parede, com o quadro, com a caixa de ferramenta, com a mão, e passa a se apresentar como um "isto" ou "aquilo" que se faz presente à vista (Vorhanden). Por sua vez, presentidade - e, portanto, também, o ente que tem esse modo de ser - só pode vir à tona em um presente (Anwesenheit aus der Gegenwart). O presente (Gegenwart) enquanto uma ekstase da temporalidade é um comportamento desvelador em que se funda o "deixar comparecer" (Begegnenlassen) do ente que "está aí" (Vorbandenen), possibilitando-o estar presente (anwesend) enquanto "isto" ou "aquilo". Lembremos que Heidegger (2012a) nos diz que essa relação entre Vorbandenen e Gegenwart se dá na medida em que o Dasein "se comporta de maneira presentificante [gegenwärtigend] em relação a algo presente à vista [Vorhandenen] e mantém esse ente como algo presente [Anwesendes] em seu presente [Gegenwart]" (p. 387). É a ekstase do

47 Quando Heidegger definiu a estrutura enquanto apofântica como um "trazer junto algo presente mostrando-o em seu estar presente deste ou daquele modo" (1976, p. 158) [“Beibringen eines Vorhandenen in seinem so und so Vorhandensein"], ele também estava dizendo que esta estrutura acarreta em um ocultamento do ente do qual o enunciado fala. Isso porque quando eu enuncio, por exemplo, "o livro é verde", com isso eu transformo, nesta tematização, o que era mero instrumento em uma mera coisa. Tal determinação do enunciado força uma modificação do autêntico caráter de ser do que foi descoberto na compreensão primária - o livro - em uma mera coisa presente [Vorhanden] dotada de propriedades que lhe são atribuídas no enunciado. 
presente que na presentificação (Gegenwärtigen) possibilita o manter o ente como algo presente (Anwesendes). A presentidade tem o seu caráter temporal demonstrado na medida em que o ente que tem o modo de ser da Vorhandenheit precisa poder deixar-se comparecer enquanto algo presente (Anwesendes) desde a presentifição (Gegenwärtigen) que se opera no presente (Gegenwart).

\section{Conclusão}

Nosso ESTUDO PRETENDEU pôr a claro como a temporalidade é condição de possibilidade da compreensão do ser do ente que tem o modo ser do que está aí presente à vista (Vorbandenen). Para tanto, foi pressuposto que acompanhassemos o modo como Heidegger desenhou, em Ser e tempo e em Os problemas fundamentais da fenomenologia, a estrutura unitária da temporalidade. A investigação nos mostrou como as ekstases da temporalidade deixam-se perceber nas suas modulações própria e imprópria. Conquistada tal etapa, voltamos a recolocar a pergunta de como a compreensão de ser do ente, no sentido do presente à vista, encontra sua possibilidade na temporalidade. A resposta imediata a tal pregunta, fornecida inclusive por von Herrmann, recorre ao argumento de que a temporalidade ekstática-horizontal, na medida em que é origem da compreensão de ser do Dasein, é o que possibilita que algo venha ao encontro do Dasein e, portanto, possa se fazer presente. Sem nos desfazermos de tal argumento, propussemos estender a fundamentação da resposta recorrendo a uma explicação prévia da temporalidade do ente que tem o modo de ser do manual (Zuhandenheit) e que, como tal, tem o seu "para que" disposto pela expectação. Percebeu-se, então, que o ente presente à vista pode vir ao encontro e ser compreendido em sua presentidade (Anwesenheit) na medida em que há uma modificação na expectação que deixa de compreender o ente a partir de seu "para que" e passa a compreendêlo como um "acerca-de-que", isto é, passa a ser antecipado e retido enquanto um "núcleo de propriedades". É sobre o fundamento de tal modificação que o ente presente à vista pode presentificar-se no modo da presentidade constante ${ }^{48}$.

48 Heidegger, no $₫ 17$ da preleção $A$ Essência da Liberdade Humana: Introdução à filosofia (2012b, pp. 182 e ss.) e nos $\$ \$ 22$ a 37 da preleção Logik. Die Frage nach der Wabrheit (1976, pp. 269 e ss), constrói ainda um outro caminho para expor a relação entre tempo e presentidade. Este caminho 
consiste fundamentalmente em recorrer às analogias da experiência que Kant (2001) desenvolve na Crítica da Razão Pura (B218 e ss). Kant descreve as analogias da experiência no contexto da Analítica dos princípios quando está a falar da representação sistemática de todos os princípios sintéticos do entendimento puro. Lá ele nos diz que a primeira analogia aponta para o princípio de permanência da substância que é formulado da seguinte forma: "Em toda mudança dos fenômenos, a substância permanece e sua quantidade não aumenta nem diminui na natureza" (B224). A segunda analogia, por sua vez, aponta para o princípio da sucessão no tempo segundo a lei da causalidade, que diz: "Todas as mudanças acontecem de acordo com o princípio da ligação de causa e efeito" (B232). A terceira analogia, por fim, aponta para o principio da simultaneidade segundo a lei da ação reciproca ou da comunidade, que rege: "Todas as substâncias, enquanto suscetíveis de ser percebidas como simultâneas no espaço, estão em ação recíproca universal" (B256). Pois bem, essas analogias da experiência ditadas por Kant são regras em que toda a experiência é representada. Contudo, como já dito, essas regras são expostas enquanto permanência, sucessão e simultaneidade, isto é, elas são expostas enquanto modos temporais. Isso significa que, para Kant, as regras que regem toda experiência e, portanto, toda aproximação como o ente presente à vista, são determinaçóes temporais. Perceba-se, no entanto, que esses modos temporais não indicam caracteres do tempo, tais como o passado, o presente e futuro, mas modos, variaçôes, como o ente que é presente à vista se relaciona com o tempo, isto é, o "como" de seu estar presente à vista, de sua presentidade. Esses modos, diz Heidegger lendo Kant, indicam a intratemporalidade do ente presente à vista, que são assim expostos por ele: "O primeiro modo - permanência - expressa a relação dos fenômenos "com o próprio tempo como uma grandeza”, isto é, a grandeza [Größe] do ser-no-tempo do ente presente à vista é a sua duração $[$ Dauer $]$. O segundo modo - resultado [Folge] (sucessão) - expressa a relação do ente presente à vista no tempo como uma série [Reihe] (resultado do agora); visto em relação a essa série, o ente presente à vista vem à tona em sua presença à vista como um depois do outro. $\mathrm{O}$ terceiro modo - concomitância [Zugleichsein] (simultaneidade) - expressa a relação do ente presente à vista com o tempo enquanto quintessência de tudo o que é presente à vista [Inbegriff alles Vorhandenen]" (Heidegger, 2012b, p. 190). Perceba-se que essa sequência que Heidegger expõe nesta análise das relações entre as analogias da experiência e os entes presentes à vista acaba por caracterizar as determinações do tempo como "série", "conteúdo", "ordem" e "conjunto". Essas determinaçôes do tempo também são expostas por Kant em B184 e 185 quando este está a tratar do esquematismo dos conceitos puros do entendimento. Para Kant, esses esquemas do entendimento "não são mais do que determinaçôes a priori do tempo, segundo regras" (B184) e que, como adiantado, "essas determinações referem-se, pela ordem das categorias, respectivamente à série do tempo, ao conteúdo do tempo, à ordem do tempo e, por fim, ao conjunto do tempo no que toca a todos os objetos possíveis" (B184-185). Embora as relações entre tempo e presentidade se mostrem bastante ricas a partir da perspectiva das analogias da experiência, não nos interessará seguir aqui com Heidegger a análise de cada um desses modos temporais. Para os nossos propósitos, basta apenas este reforço na consolidação da relação entre tempo e presentidade dado pela indicação de que as analogias da experiência apontam para uma determinação temporal do ente presente à vista e que, portanto, cabe a tais determinaçôes ditar o modo de ser do ente presente à vista, isto é, o "como" de sua presentidade. Acerca dos estudos desenvolvidos sobre a questão do tempo entre Kant e Heidegger vide Sherover (1971), Heidegger, Kant and Time e Käufer (2013, pp. 345-350). 
Referências bibliográficas

Corti, C. A. (2006). Zeitproblematik bei Martin Heidegger und Agustinus. Würzburg: Königshausen \& Neumann.

Dastur, F. (1999). Heidegger and the Question of the Time. New York: Humanity Books.

Dostal, R. J. (1993). Time and Phenomenology in Husserl and Heidegger. The Cambridge Companion to Heidegger (pp. 141-169). Cambridge: Cambridge University Press.

von Falkenhayn, K. (2003). Augenblick und Kairos. Zeitlichkeit im Frub̈werk Martin Heideggers. Berlin: Duncker \& Humblot.

Farrell, R. B. (1977). Dictionary of German Synonyms. Cambridge: Cambridge University Press.

Haar, M. (1990). Heidegger e a essência do homem. Lisboa: Instituto PIAGET.

Heidegger, M. (1976). Logik. Die Frage nach der Wahrheit. Gesamtausgabe Band 21. Frankfurt am Main: Vittorio Klostermann.

Heidegger, M. (1978). Metaphysische Anfangsgründe der Logik im Ausgang von Leibniz. Gesamtausgabe Band 21. Frankfurt am Main: Vittorio Klostermann. Heidegger, M. (1989). Beiträge zur Philosophie. Gesamtausgabe Band 65. Frankfurt am Main: Vittorio Klostermann.

Heidegger, M. (2006a). Die Metaphysik des deutschen Idealismus (Schelling). Gesamtausgabe Band 49. Frankfurt am Main: Vittorio Klostermann.

Heidegger, M. (2006b). Sein und Zeit. Tübingen: Max Niemeyer.

Heidegger, M. (2008). Ser e tempo. (Trad. M. S. Calvacanti). Petrópolis: Vozes. Heidegger, M. (2012a). Os problemas fundamentais da fenomenologia. (Trad. M. A. Casanova). Petrópolis: Vozes.

Heidegger, M. (2012b). A essência da liberdade humana: introdução à filosofia. (Trad. M. A, Casanova). Rio de Janeiro: Via Verita.

Heinz, M. (1986). The Concept of Time in Heidegger's Early Works. In: J. J. Kockelmans (Ed.). A Companion to Martin Heidegger's "Being and Time" (pp. 183-207). Washington: University Press of America.

von Herrmann, F.-W. (1997). La segunda mitad de Ser y Tiempo. Sobre Los problemas fundamentales de la fenomenología de Heidegger. (Trad. I. BorgesDuarte). Madrid: Trotta. 
von Herrmann, F.-W. (2004). Subjekt und Dasein. Frankfurt am Main: Klostermann Seminar.

Inwood, M. (2002). Dicionário Heidegger. Rio de Janeiro: Jorge Zahar.

Kant, I. (2001). Crítica da Razão Pura. (Trad. M. P. dos Santos). Lisboa: Fundaçao Calouste Gulbenkian.

Käufer, S. (2013). Temporality as the Ontological Sense of Care. In: M. A. Wrathall (Ed.) The Cambridge Companion to Heidegger's Being and Time (pp. 338-359). Cambridge: Cambridge University Press. Dor: 10.1017/ CCO 9781139047289.016

Másmela, C. (2000). Martin Heidegger: El tiempo del Ser. Madrid: Trotta.

Másmela, C. (2016). La filosofía del Entre en Heidegger: una interpretación de las Contribuciones a la filosofía. Buenos Aires: Biblos.

Massey, H. (2015). The Origin of Time. Heidegger and Bergson. Albany: Suny Press.

Nicholson, G. (1986). Ekstatic Temporality in Sein und Zeit. In: J.J. Kockelmans (Ed.). A Companion to Martin Heidegger's "Being and Time" (pp. 208-226). Washington: University Press of America.

Pearl, J. (2013). A Question of Time. Freud in the Light of Heidegger's Temporality. Amsterdam: Editions Rodopi.

Peñalver, P. (1989). Del espiritu al tempo. Lecturas de "El ser y el tempo" de Heidegger. Barcelona: Anthtropos.

Rozo, M. G. (2005). Fuera de casa o de la existencia impropia. Hacia otra lectura de Ser y Tiempo de Heidegger. Bogotá: Universidad de los Andes.

Sembera, R. (2007). Rephrasing Heidegger. A Companion to Being and Time. Ottawa: The University of Ottawa Press.

Shereover, Ch. (1971). Heidegger, Kant and Time. Bloomington, IN: Indiana University Press.

Thomé, M. (1998). Existenz und Verantwortung. Würzburg: Königshausen \& Neumann.

Vetter, H. (2016). Parmenides. Sein und Welt. München: Verlag Karl Alber.

White, C. J. (2005). Time and Death. Heidegger's Analysis of Finitude. Aldershot: Ashgate. 